Portland State University

PDXScholar

Fall 2012

\title{
Connecting Habitat Across Roads: Field Testing Mitigation Strategies for Reducing Road Mortality of an Imperiled Butterfly
}

Rebecca Jalene Littlejohn

Portland State University

Follow this and additional works at: https://pdxscholar.library.pdx.edu/mem_gradprojects

Part of the Environmental Monitoring Commons

Let us know how access to this document benefits you.

\section{Recommended Citation}

Littlejohn, Rebecca Jalene, "Connecting Habitat Across Roads: Field Testing Mitigation Strategies for Reducing Road Mortality of an Imperiled Butterfly" (2012). Environmental Science and Management Professional Master's Project Reports. 24.

https://pdxscholar.library.pdx.edu/mem_gradprojects/24

https://doi.org/10.15760/mem.16

This Project is brought to you for free and open access. It has been accepted for inclusion in Environmental Science and Management Professional Master's Project Reports by an authorized administrator of PDXScholar. Please contact us if we can make this document more accessible: pdxscholar@pdx.edu. 


\section{Connecting Habitat Across Roads: Field testing mitigation strategies for reducing road mortality of an imperiled butterfly}

by Rebecca Jalene Littlejohn

Master of Environmental Management Project

School of the Environment

Portland State University

Final Project Submitted: December 11, 2012 


\section{Contact Information \& Acknowledgments}

\section{Contact Information}

R. Jalene Littlejohn

Advisor: Catherine E. de Rivera|(503) 725-9798 | derivera@pdx.edu

\section{Committee Members}

Catherine E. de Rivera, Professor, Environmental Science and Management, Portland State University

Martin Lafrenz, Professor, Geography, Portland State University

Anne Walker, US Fish \& Wildlife Service

\section{Acknowledgments}

This project would not have been possible without the support, mentoring and guidance from my advisor, Catherine E. de Rivera and lab. Technical support and data were instrumental from Anne Walker at the U.S. Fish and Wildlife Service, Marty Bray and Michelle Dragoo at the U.S. Forest Service, and reports/data from others that have been working on recovery of the Oregon silverspot butterfly. I am very appreciative of my committee members who took time out of their busy schedule to read and suggest edits to the paper, data and presentation. I am grateful for the in-kind support from Bosky Dell Natives, a leading northwest natives nursery in the region. And last but not least, a huge thank you to all the tireless volunteers who helped collect data this summer and the countless support and guidance from colleagues at the U.S. Fish \& Wildlife Service.

\section{Interaction with Partners - MEM requirement}

Anne Walker from the U.S. Fish \& Wildlife Service served as the community partner on my committee. Anne assisted with technical support, reviewed data and results, and attended the final presentation with project comments. I also participated in Oregon silverspot butterfly partners/recovery team meetings and will submit the project to this team for Anne to keep on record. Additionally, I worked closely with partners from the U.S. Forest Service, Michelle Dragoo and Marty Bray, both out of the Siuslaw National Forest office. I received technical support, data, and draft comments from partners at the Forest Service. 


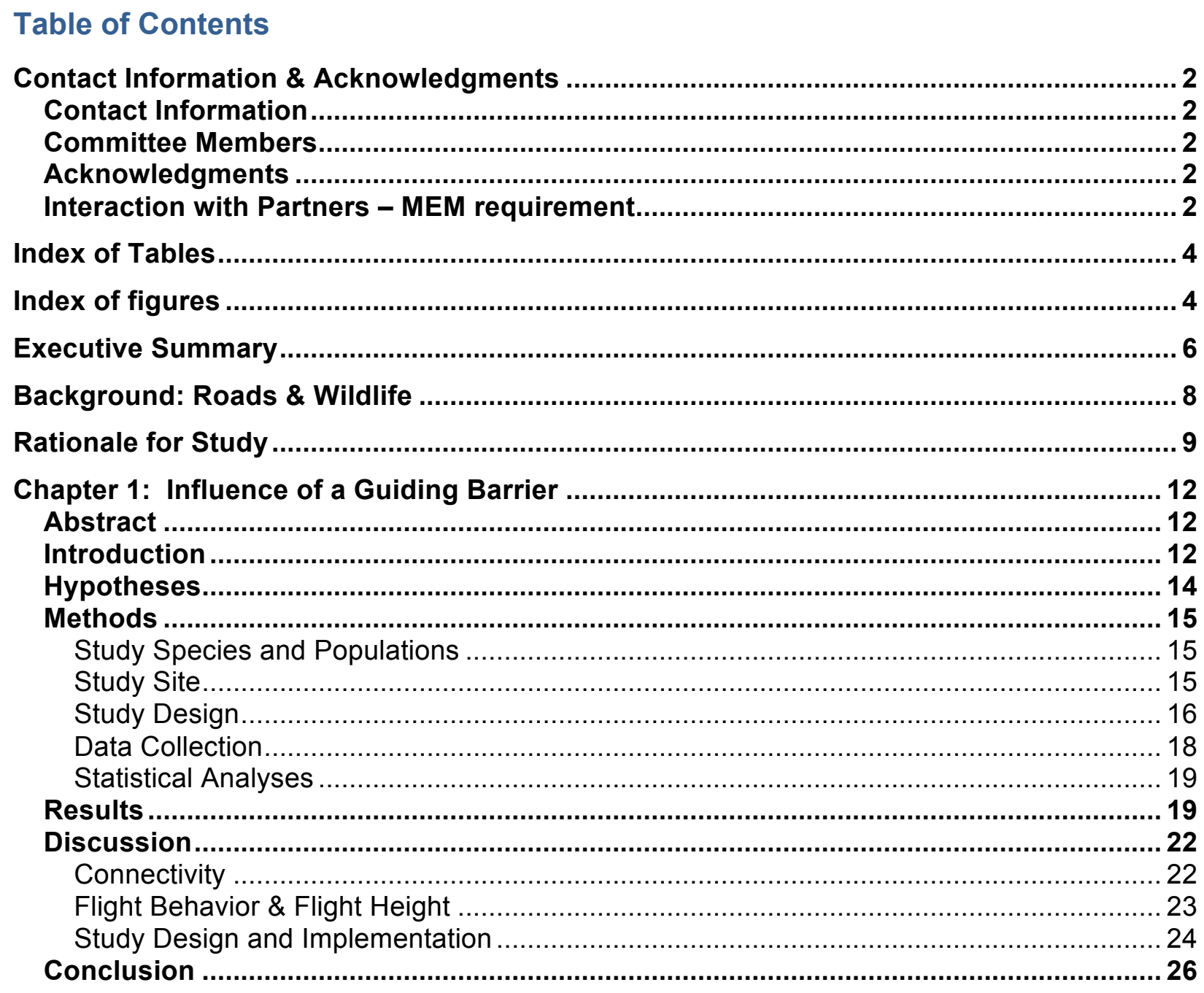

Chapter 2: Vegetation height along Highway 101 at Rock Creek, Big Creek and nearby management areas in the Siuslaw National Forest .......................................................... 28

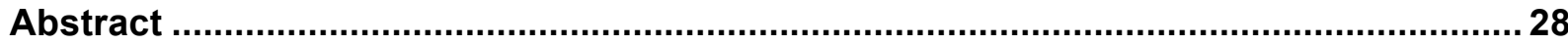

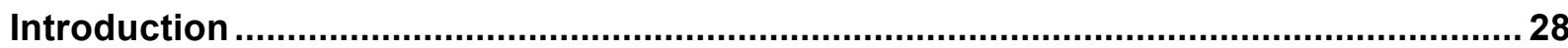

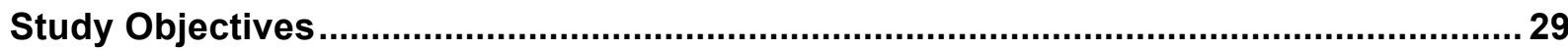

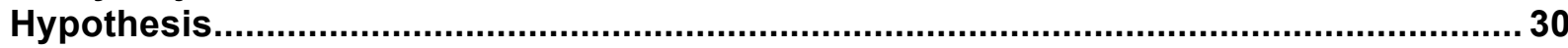

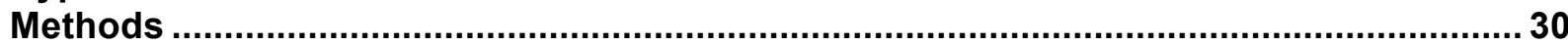

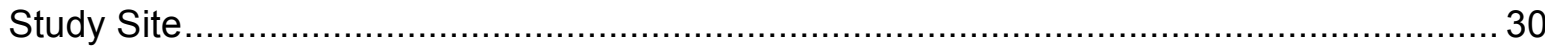

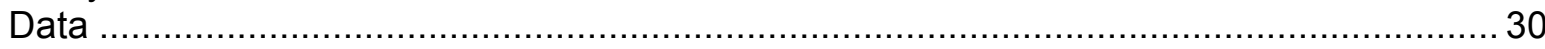

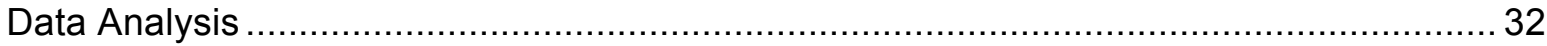

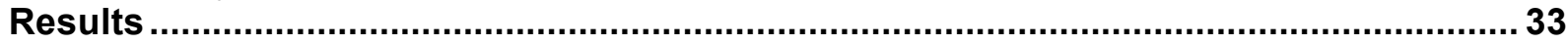

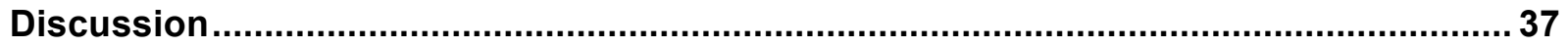

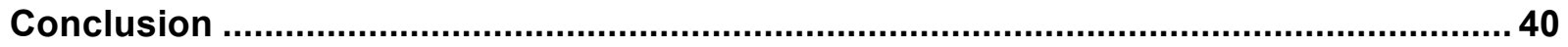

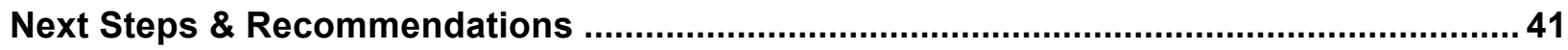

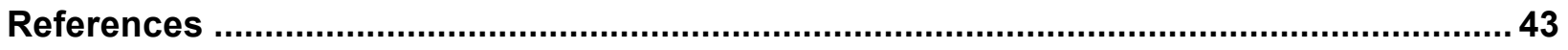

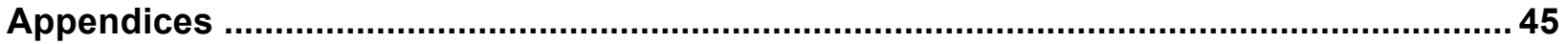

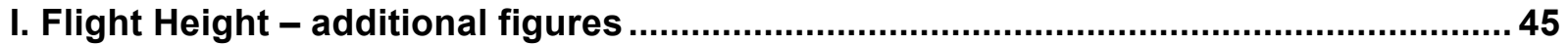

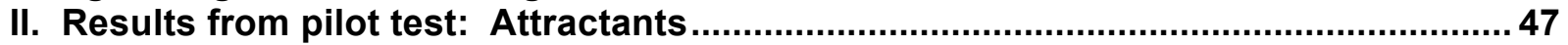

by Rebecca Jalene Littlejohn

Connecting habitat across roads 


\section{Index of Tables}

Table 1: Description of behavior classifications used in the experimental guiding barrier study for each individual butterfly that flew within one meter of the studied section.

Table 2: Mean, median, minimum and maximum values for weather conditions across all trials

Table 3: Frequency of observed flight path behaviors, comparing between treatments with a net and no net.

Table 4: Number of individuals and percent of total butterflies that crossed both pole-crossings

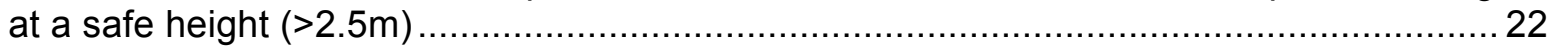

Table 5: Data used in spatial analysis, sources, and associated analyses ........................... 30

Table 6: Flight height descriptive statistics by trial between treatments (net vs. no net) .......... 45

Table 7: Wilcoxon rank sum test results for flight height between treatments (net vs. no net) for each trial

\section{Index of figures}

Figure 1: Image of Rock Creek - Big Creek site where Oregon silverspot butterflies are found. Highway 101 bisects the habitat; habitat resources are found on both the east and west sides of the highway. Photo credit: Anne Walker, US Fish \& Wildlife Service................... 9

Figure 3: Image of one pole-crossing spanning the width of the roadway. Total width of the pole-crossing from pole A (left pole) to pole B (right pole) is about 7 meters. Complete set up for each trial included two pole crossings with 8 meters of roadway from north to south between the two crossings......

Figure 4: Road delineation from north to south in 8-meter sections (not to scale) from 1-10. Figure shows an example of how a trial was set up at a randomly selected section of the roadway using two poles on each side of the road. Poles a-b created one pole-crossing, and poles $\mathrm{c}-\mathrm{d}$ created the second pole-crossing with 8 meters from north-to-south between the pole crossings. Six trials were conducted at different randomly selected sections....... 18

Figure 5: Percentage of individual butterflies that were able to travel the corridor (behaviors: through, around, over) vs. those that did not travel the corridor (behavior: turn around).... 20

Figure 6: Percentage of individual butterflies that landed in the middle of the two pole-crossings. Comparison of treatments with a net vs. no net for all butterflies that flew through, around, or over.

Figure 7: Site map of study area for spatial analysis of vegetation height along Highway 101 adjacent to S. z. hippolyta habitat.

Figure 8: mean vegetation height within aggregated sample areas (left) and between individual highway crossing points from the Zielin (2009) study (middle) and Bennett study (2010; right).

Figure 9: Map of Rock Creek Meadows, managed by the USFS Siuslaw National Forest. Points indicate the highway crossing points from Bennett 2010 and Zielin 2010. Vegetation height is classified in meters within a 40-meter buffer on each side of the highway. 35

Figure 10: map of Rock Creek-Big Creek site identifying violet densities, highway crossing points, and vegetation height adjacent to the highway. Visual analysis shows that most of the crossing points are located in areas of low vegetation and between densely located habitat resources (violets).

by Rebecca Jalene Littlejohn

Connecting habitat across roads

Page 4

$12 / 11 / 12$ 
Figure 11: Map of Bray Point meadows, managed by the USFS Siuslaw National Forest. No highway crossing data are available for these sites. Vegetation height is classified in meters within a 40-meter buffer on each side of the highway. Violet count densities are highlighted in purple at the Bray Point site. No habitat data is available at the other restoration sites.

Figure 12: Flight height in the middle of the pole-crossings by location. Determined to be similar by visual analysis, thus all flight height data was pooled for statistical analysis.

Figure 13: Range of flight height (in meters) of individuals, comparing treatments with a net vs. no net....

Figure 14: Range of flight height (in meters) of individuals that flew "around" vs. "over"

Figure 15: Figure shows the ratio of butterflies that landed or flew within one meter of the treatment pole to the total number of butterflies observed in the area prior to the observation period. No butterflies landed on any of the treatment poles during pilot tests. 


\section{Executive Summary}

Roads impact wildlife in a variety of ways including fragmentation of populations, reduced access to habitat, and direct mortality from vehicle strikes. Such road effects likely impact the Oregon silverspot butterfly (Speyeria zerene hippolyta) at one of its few remaining sites. The Rock Creek-Big Creek population of this threatened fritillary butterfly species is bisected by highway 101 on the central Oregon coast. Habitat resources for S. z. hippolyta are found on both the east and west sides of the highway at this site, and vehicle-strikes have been found to cause mortality of some individuals crossing the highway. The 2001 revised Recovery Plan calls out road mortality as a primary threat to $S$. $z$. hippolyta and land managers are considering mitigation strategies to reduce this threat on the population. A previous study at Rock CreekBig Creek prioritized mitigation strategies including mowing of the road sides to decrease flowering plants along the verge and installation of vegetative hedgerows along the highway where the butterflies are crossing to encourage increased flight height over the road. Mowing has taken place over the last two years, but the hedgerows have neither been installed nor tested for effectiveness.

This study investigates the effectiveness of hedgerows to increase the flight height of S. $z$. hippolyta through experimental tests using 3-meter tall nets as "guiding barriers" to mimic vegetative hedgerows in the flight path of S. z. hippolyta at another site in Oregon, Mt. Hebo. Mt. Hebo was chosen because of the stable population of S. z. hippolyta that is found there, the low risk of mortality for individual butterflies during the course of the study, and consistent use of a corridor by S. z. hippolyta. Treatments were designed to mimic a flight path in which a butterfly encounters a "road" of a width simulating that of highway 101 with 3-meter guiding barriers on either side. Based on previous research observations, it was hypothesized that S. $z$. hippolyta individuals would fly over the guiding barriers at an increased "safe" flight height such that they would fly over traffic height. Results of the experimental study indicated that a 3-meter 
guiding barrier in the flight path of S. z. hippolyta did not significantly increase the flight height of individuals. None of the individuals observed flew at a safe flight height over the road (>3 meters). Further, S. z. hippolyta individuals landed on the road surface more often when there was a guiding barrier in the flight path. These results suggest that while S. z. hippolyta individuals are able to fly over guiding barriers in their path at heights of 3 meters or more, there is no evidence to suggest that these structures will influence flight height over highway 101 such that road mortality is reduced.

Additionally, this study investigated the known butterfly crossing points at Rock Creek-Big Creek to test the hypothesis that S. z. hippolyta individuals are crossing at points of lower vegetation adjacent to the road. Using data from previous studies, ten crossing points were mapped at this site. Light detection and ranging data (LiDAR) was used to derive vegetation height along highway 101 and analyzed between known crossing points and random points within the Rock Creek-Big Creek area in addition to resource density of the larval host plant (Viola adunca) within the meadows. Statistical analysis indicated that the butterflies were generally crossing at points along the highway with significantly lower vegetation adjacent to the road. Visual analysis indicated that the butterflies were also generally crossing between areas of densely located $V$. adunca. Additional spatial data is needed to do further path-analysis of $S$. $z$. hippolyta individuals.

Strategic choices need to be made regarding management of S. z. hippolyta habitat resources to reduce road mortality. Results from this study indicate that guiding barriers may not be an effective strategy to consider at this time. This study confirms that S. z. hippolyta individuals are crossing the highway between habitat resources in areas with lower vegetation adjacent to the roadway. Thus, the following management strategies are recommended: 1) continue mowing the road verges to reduce attraction to the road by reducing resource availability; 2) increase 
efforts to restore habitat resources on the east side of the highway, rather than the west side to decrease the need for butterflies to cross the road; 3) maintain corridors between restored meadows on the east side of the highway; and 4) maintain spatial data records as part of the recovery reporting for ease in analysis and planning.

\section{Background: Roads \& Wildlife}

Transportation infrastructure, such as roads and highways, negatively affects ecosystems and wildlife in a variety of direct and indirect ways (Coffin 2007; R. Forman and Alexander 1998). Ecological impacts include habitat and population fragmentation, reduced access to habitat, and direct mortality among others (Jackson 2000; R. Forman and Alexander 1998; Coffin 2007). Roads have been suggested to affect the surrounding environment far beyond the footprint of the road (R. T. T. Forman 2000). Studies have found negative effects on species up to $5 \mathrm{~km}$ from the road (Benítez-López, Alkemade, and Verweij 2010) and Forman \& Alexander (1998) estimated that $15-20 \%$ of the U.S. landscape is affected by the "road zone".

The effects that roads have on organisms vary among species (Coffin 2007; Brock and Kelt 2004). Roads may simultaneously have some positive and some negative effects on different species. Roadsides may provide habitat for some species (Brock and Kelt 2004; R. Forman and Alexander 1998) such as generalists or species that thrive in disturbed environments, while decreasing habitat area and/or access for more sensitive species. For example, some pollinators are attracted to weedy flowering plants along road corridors (Munguira and Thomas 1992; Bruckmann, Krauss, and Steffan-Dewenter 2010), but those that live adjacent to or cross roadways are faced with the possibility of direct vehicle-caused mortality among other challenges to habitat access (Rao and Girish 2007). Road mortality can cause reductions in population size, and is even considered a primary source of mortality for some species (R. Forman and Alexander 1998; Sillero 2008; Jackson 2000), but habitat connectivity across roads 
is important to sustaining population viability (reviewed in Glista et al. 2009). Therefore, the challenge emerges of reducing animal-vehicle collisions while maintaining habitat connectivity, especially for sensitive populations.

\section{Rationale for Study}

The Oregon silverspot butterfly (Speyeria zerene hippolyta) is a threatened butterfly species that has been extirpated from much of its historical range due to habitat loss and degradation (USFWS 2001). One coastal meadow habitat area in Oregon, Rock Creek-Big Creek, where $S$. z. hippolyta is located comprises habitat resources on both the east and west sides of Highway 101 (fig 1). S. z. hippolyta individuals have been observed to use habitat resources on both sides of the highway, including the verges (the area directly adjacent to the road surface) (Bennett 2010; Zielin 2010). Individuals have been observed crossing the highway between habitat fragments and a few vehicle strikes have been recorded (Bennett 2010; Zielin 2010). The revised recovery plan (2001) calls out vehicle-caused mortality as a primary threat to the butterfly's recovery, but the specific impact of the highway and mitigation strategies that will be most useful to reduce road mortality are not well understood.

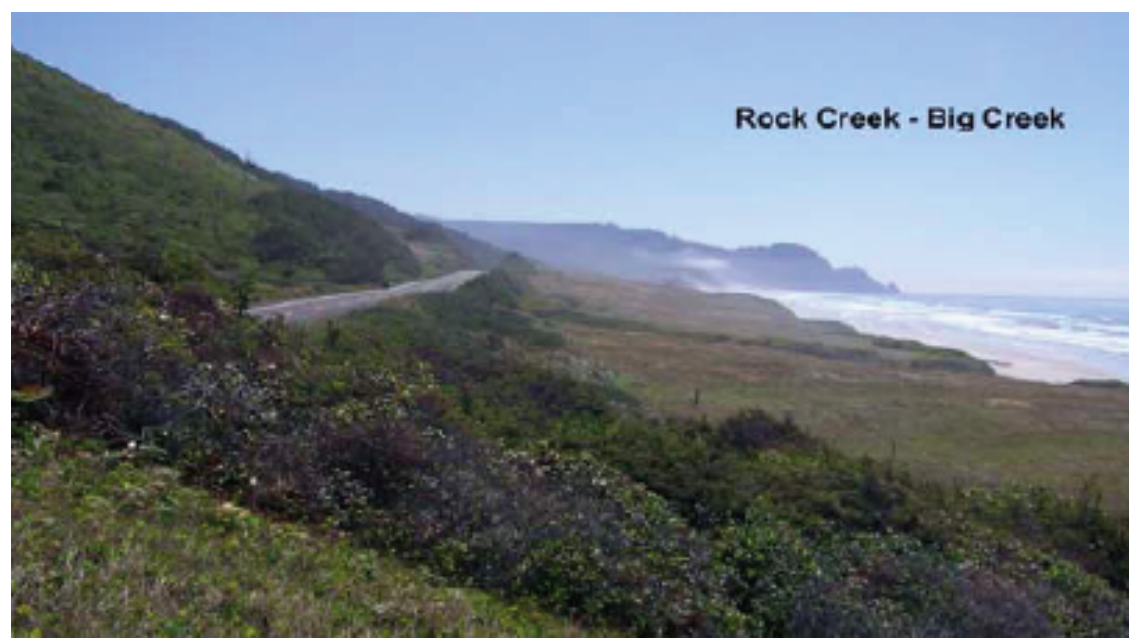

Figure 1: Image of Rock Creek - Big Creek site where Oregon silverspot butterflies are found. Highway 101 bisects the habitat; habitat resources are found on both the east and west sides of the highway. Photo credit: Anne Walker, US Fish \& Wildlife Service. 
Several management options were developed to address possible risk from butterfly-vehicle collisions to the Rock Creek-Big Creek population of S. z. hippolyta. Field research was conducted in 2009 on the ecology and behavior of S. z. hippolyta at this site to prioritize these management options. Because these butterflies crossed more often where there were nectar plants along the verge, mowing the verge was recommended as the top management priority (Zielin 2010). As a result, the Oregon Department of Transportation (ODOT) began mowing the verge of Highway 101 at this site in 2010. The second prioritized management option was to install hedgerows or some other type of guiding barrier that would induce butterflies to fly higher over the road, to increase the likelihood of flight over passing traffic, thus reducing the chance of road mortality yet maintaining habitat connectivity (henceforth, 'guiding barrier'). In a follow up study in 2010 , butterflies were observed to fly at heights ranging from $2-7$ meters, relative to the adjacent roadside vegetation suggesting again that guiding barriers may be a worthy management option (Bennett 2010).

These two studies reached somewhat different conclusions. For example, Zielin (2009) found that road mortality may present a high risk while the Bennett (2010) study concluded it likely did not. These studies may have reached different conclusions because 1) the verge was already being mowed for the 2010 study, which may have reduced attraction to the road; 2) they used different methods, with sitting observers in the Zielin study versus active followers of butterflies in the Bennett study; and/or 3) weather conditions stimulated differences. Despite their differences, both studies suggested that hedgerows or similar guiding barriers along the verge would likely induce S. z. hippolyta to fly higher over the road.

Most of the literature on connecting habitat across roads for flying species has focused on birds and bats, rather than invertebrates (Glista, DeVault, and DeWoody 2009; Jackson 2000; Kintsch and Cramer 2011; Bank et al. 2002, Metro 2010). Management reports, such as a review 
compiled in Washington State in 2011, commonly incorporate flying invertebrates, such as butterflies, in the same category as these species (Kintsch and Cramer 2011). Guiding barriers such as poles and planted medians have been effective management strategies for bird species to encourage flight over traffic across a road (Jacobson 2005; Kintsch and Cramer 2011), but there is little evidence beyond speculation that this "guiding barrier" method will work effectively for butterflies. Further, management-planning options commonly include overpasses or land bridges as effective management strategies for flying species (Glista, DeVault, and DeWoody 2009; Bank et al. 2002; Kintsch and Cramer 2011, Metro 2010). It is unlikely that a land bridge will be considered along Highway 101 for S. z. hippolyta to cross between meadows. By combining strategic placement of guiding barriers and attractants, it may be possible to create a "virtual bridge" in which butterflies are attracted to cross the road at specific locations.

This study aimed to build on two prior studies (Bennett 2010; Zielin 2010) to investigate whether guiding barriers will effectively increase flight height of S. z. hippolyta and to understand the current state of vegetation along the highway where S. z. hippolyta individuals are crossing the road. While this research focuses on a management strategy for one species at a single site, the implications of the study will help to fill a gap in the literature regarding mitigation of road mortality of butterflies and other flying invertebrates. 


\title{
Chapter 1: Influence of a Guiding Barrier
}

\author{
Abstract \\ Roads have wide-ranging impacts on wildlife populations and negative impacts have been \\ documented far beyond the footprint of the roadway. Design, management, location and use of \\ roads have varying impacts on different species. The Oregon silverspot butterfly (Speyeria \\ zerene hippolyta) is a threatened butterfly species that has been extirpated from most of its \\ range along the west coast of the United States. One site (Rock Creek-Big Creek) where a \\ small population of S. z. hippolyta remains is bisected by Highway 101, a two-lane highway that \\ is used most during the summer tourist season which coincides with the flight season of the $S$. \\ z. hippolyta. Habitat resources are found on both sides of the highway and past researchers \\ have observed road crossings and vehicle-caused mortality. Experimental tests were \\ conducted to test vegetative hedgerows as a mitigation strategy to increase flight height of S. $z$. \\ hippolyta over the road and decrease vehicle-caused road mortality. Three-meter tall nets were \\ used in the study design to mimic vegetative hedgerows as a guiding barrier within the flight \\ path. The guiding barrier nets placed in the flight path of S. z. hippolyta did not significantly \\ reduce connectivity through a corridor ( $76 \%$ traveled the corridor with a net in place). However, \\ these nets did not significantly increase flight height (net: $1.01 \mathrm{~m}$ vs. no net: $0.83 \mathrm{~m}$ ) and may \\ increase the number of individuals that land on the roadway (net:19\% vs. no net: $7 \%$ ). Further, \\ none of the sampled individuals flew at a height of 3 meters over the guiding barriers, and only \\ $7 \%$ flew at a height of 2.5 meters or more. Results suggest that vegetative guiding barriers \\ alone may not be a sufficient mitigative solution to increasing safe flight height across the \\ highway for S. z. hippolyta.
}

\section{Introduction}

Commonly, mitigation strategies to reduce road mortality are designed to aid large vertebrates or mammals that cause economic damage and possible human death when vehicle strikes 
occur, rather than insects and pollinators (Glista, DeVault, and DeWoody 2009; Jackson 2000; Bank et al. 2002; Corlatti, Hackländer, and Frey-Roos 2009; Kintsch and Cramer 2011, Metro 2010). Pollinators, like the Oregon silverspot butterfly (Speyeria zerene hippolyta) have been observed to utilize road verges (Zielin 2010; Bennett 2010) and can cross a road relatively easily compared to other sensitive species that can not fly (Munguira and Thomas 1992), though they may still be subject to vehicle-caused mortality (Munguira and Thomas 1992; Rao and Girish 2007). Studies have shown that direct road mortality may threaten animal populations (R. Forman and Alexander 1998). A study by Munguira \& Thomas (1992) found that between $10-32 \%$ of marked and recaptured burnet butterflies had crossed a road in their study areas and estimated a range of $1-7 \%$ were killed on the road. This 1992 study suggested that the road and vehicle traffic are not a barrier to movement or a significant threat to population of burnet butterflies. Although, they also pointed out that recaptures consisted of mostly common species, rather than rare or threatened species. A study by Rao and Girish (2007) reported high densities of butterfly road kill that increased with traffic volume, but could not report whether road kill densities negatively impacted populations. Further, this 2007 study found that higher-flying species surveyed in meadows adjacent to the road were not found in road kill samples. These studies suggest that while roads are not barriers to movement for flying invertebrates, vehicle-caused mortality occurs for low-flying species and more information is needed regarding the impact to populations. Regardless of the species, habitat and population fragmentation, barriers to movement, and direct mortality are common themes in the literature about road impacts on wildlife (Coffin 2007) and remain a concern for recovery of S. $z$. hippolyta.

Two management strategies are utilized to reduce road mortality of wildlife: 1) modification of the target animal's behavior; or 2) modification of human behavior (Glista, DeVault, and DeWoody 2009). For example, Shwiff et al. (2002) highlighted the success of poles installed on 
the sides of a bridge in Florida where royal terns were commonly killed when flying over the bridge at a height that caused collisions with cars. These poles caused terns to modify their flight height over the bridge to fly over traffic. Modification of human behavior includes strategies such as reduction of speed limits, signs, and lighting (Glista, DeVault, and DeWoody 2009). At this time, modification of the behavior of S. z. hippolyta has been prioritized over modification of human behavior to reduce road mortality. Previous research suggests that vegetation height alongside the highway may be influencing the flight height of S. z. hippolyta across the road (Bennett 2010; Zielin 2010). Thus, land managers are considering putting resources toward the establishment of taller vegetative hedgerows along the highway where butterflies are crossing between habitat resources. These vegetative hedgerows are expected to act as guiding barriers, similar to the poles in the Shwiff et al. example for royal terns (2002), to increase the flight height of S. z. hippolyta and thus increase the probability that individuals will fly at a safe height over traffic. The efficacy of this strategy has not been tested.

This study seeks to answer the following research questions:

1. Will the act of placing a 3-meter guiding barrier in the flight path of the butterflies decrease connectivity between habitats?

2. What flight behavior will S. z. hippolyta exhibit when flying up to a 3-meter guiding barrier in their flight path?

3. If S. z. hippolyta flies over the guiding barrier, at what height will S. z. hippolyta individuals fly over a road when there is a 3-meter guiding barrier in their flight path?

\section{Hypotheses}

- The act of placing a 3-meter guiding barrier in the flight path of S. z. hippolyta will not decrease corridor connectivity

- S. z. hippolyta will fly over a guiding barrier placed in their flight path

- S. z. hippolyta flight height will increase when a guiding barrier is placed in their path 


\section{Methods}

\section{Study Species and Populations}

The species of study is the Oregon silverspot butterfly (Speyeria zerene hippolyta), a fritillary

butterfly that is federally listed as threatened. It inhabits coastal meadows/marine terraces, montane grasslands, and stabilized dunes along the west coast (USFWS 2001). It is now only found in a few remaining populations, one of which is the Rock Creek-Big Creek population along the central coast of Oregon. Highway 101 bisects this population's habitat. However, this population is fairly small and it was not deemed safe for observers or butterflies to conduct roadside research along Highway 101. Therefore, observations were conducted at Mt. Hebo, which is the site of a larger, more stable population. The Rock Creek-Big Creek population has been augmented over the past 20 years through a captive rearing program at the Oregon and Woodland Park Zoos, including stock from the Mt. Hebo population. Therefore, even if the butterflies among the different populations have developed different behaviors over time, Mt. Hebo stock can be found in the Rock Creek-Big Creek population and findings from Mt. Hebo are likely relevant to management of Rock Creek-Big Creek.

\section{Study Site}

The study was conducted using a decommissioned roadway on Mt. Hebo in the Siuslaw National Forest in Oregon that was frequently being used as a travel corridor by S. z. hippolyta (fig 2).

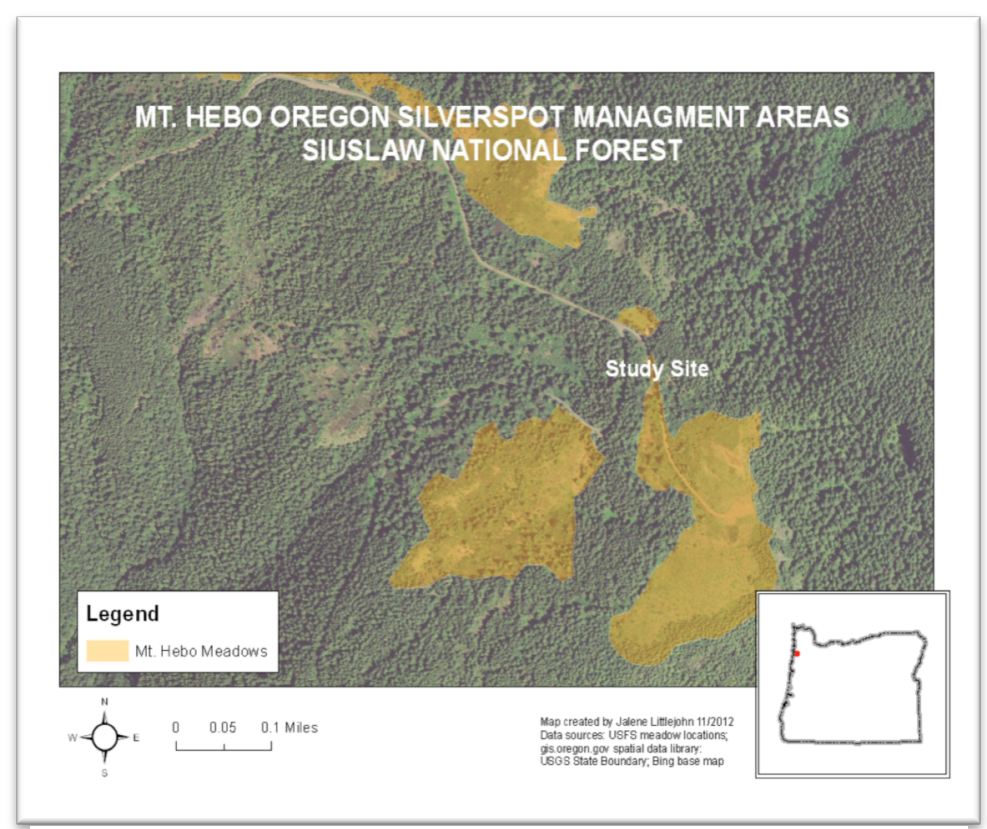

Figure 2: Map of Mt. Hebo meadows where S. z. hippolyta is found and the site where the study took place along a decommissioned road that leads to one of the meadows. 
The study site was chosen based on three factors:

1. Availability of S. z. hippolyta: The site is located on a decommissioned road that leads to a meadow currently under management by the U.S. Forest Service for S. z. hippolyta.

2. Observed use of a corridor by S. z. hippolyta: Individuals were observed to fly in a northto-south path using the decommissioned roadway for travel between meadows.

3. No risk of mortality or harm to butterflies or habitat: The study was not conducted near a road with traffic because of the increased risk of mortality for S. z. hippolyta throughout the course of the study. The study was designed to have no negative impact on the butterflies or their habitat.

\section{Study Design}

The decommissioned road ("roadway") was delineated into 10 sections from north to south along the length of the roadway (fig 4). Six trials were conducted; each in a different randomly selected section of the roadway. For each trial, the section was marked using two sets of eastto-west pole-crossings: a northern pole-crossing (poles a-b, figure 4) and a southern polecrossing (poles c-d, fig 4) that buffered the width of the roadway by about 2 meters (fig 3). The width of the pole-crossings was determined by pilot tests in which butterflies were observed to fly down the center of the roadway, utilizing the sunniest sections of the roadway and verge. The pole-crossings were standardized at a width of approximately 7 meters to span the entire width of the roadway and the sunniest sections of the verge. Sections measured 8 meters from north to south to simulate the width of a 2-lane road that the butterflies would cross in their flight path (fig 4).

Each trial consisted of four consecutive 15-minute observation periods in which both polecrossings either had a 3-meter tall net (3/4" polypropylene mesh bird netting) stretched between the poles or no net while the poles remained standing (fig 4). Average flight height observed 
was around one meter and pilot tests indicated that butterflies would fly over 1-meter, 2-meter, and 3-meter nets in their flight path. Therefore, a 3-meter net was used as it is likely taller than many standard vehicles and serves as a better test for the hypotheses.

It was randomly chosen whether there would be a net or no net for the first and third observation periods of the trial. The opposite placement was chosen for the second and fourth periods of the trial. For example if "net" was randomly chosen for the first observation period, then the second period would be "no net" and so on. Thus, each complete trial consisted of two sets of net and two sets of no net treatments.
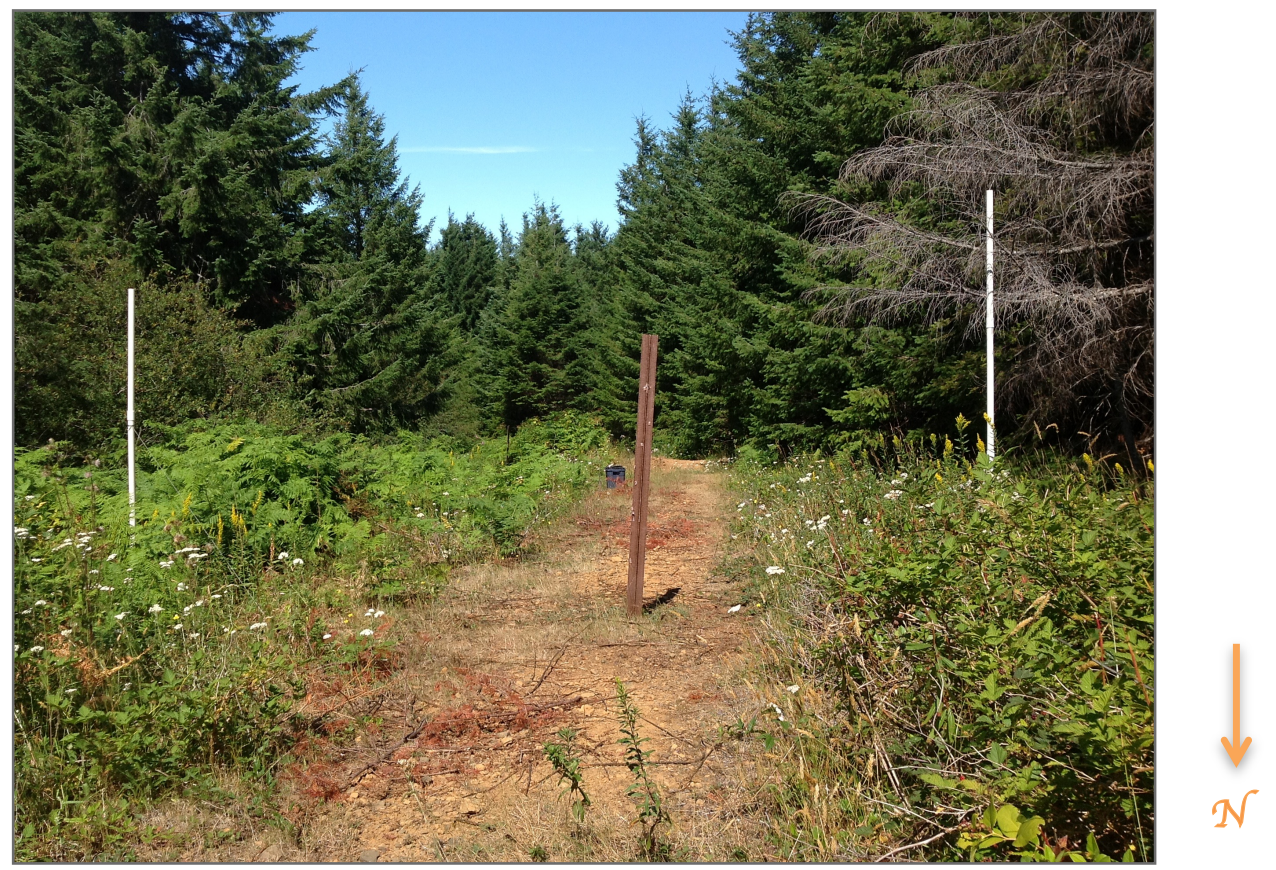

Figure 3: Image of one pole-crossing spanning the width of the roadway. Total width of the pole-crossing from pole A (left pole) to pole B (right pole) is about 7 meters. Complete set up for each trial included two pole crossings with 8 meters of roadway from north to south between the two crossings. 


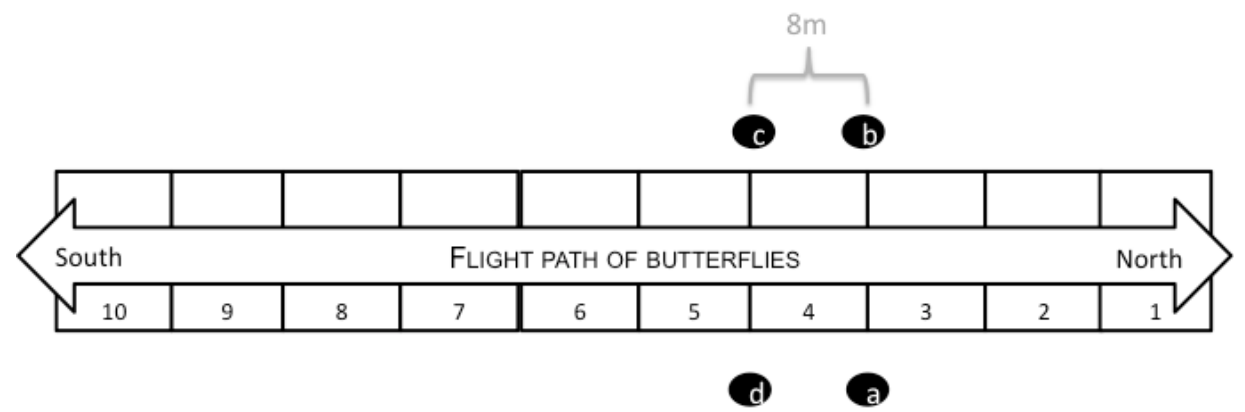

Figure 4: Road delineation from north to south in 8-meter sections (not to scale) from 1-10. Figure shows an example of how a trial was set up at a randomly selected section of the roadway using two poles on each side of the road. Poles a-b created one pole-crossing, and poles c-d created the second pole-crossing with 8 meters from north-to-south between the pole crossings. Six trials were conducted at different randomly selected sections.

\section{Data Collection}

Data were collected during the known flight season of the Mt. Hebo butterflies between August - September (Patterson 2010) during the sunniest hours of the day (12:00 - 4:00 p.m.). Data collection ceased for the day when there were shade patches on the roadway and for the season when there were fewer than five butterflies observed.

Wind speed, temperature, and relative humidity were measured before each observation period in all trials. Throughout each 15-minute period, the behavior and flight height of each individual butterfly that flew within one meter of the section of study was recorded. The following data were collected for each individual: species, flight direction, behavior (table 1), flight height at the first encountered pole-crossing in their flight path, flight height in between the two polecrossings (in the middle of the 8 meter section), and flight height at the second pole-crossing encountered in the flight path. Species assignment was based on best available identification made by the observer in the field. Behavior for each individual was recorded at or within one meter of the first pole-crossing encountered in the flight path (table 1). Flight height was estimated by comparing height of the recorded individual to marked indicators on the closest pole. All individuals that flew within one meter of the section of study, regardless of species, 
were observed, but only those that were presumed to be Oregon silverspot butterflies were used in analysis.

Table 1: Description of behavior classifications used in the experimental guiding barrier study for each individual butterfly that flew within one meter of the studied section

\begin{tabular}{|c|c|}
\hline Behavior & Description \\
\hline "Around" & $\begin{array}{l}\text { An individual that flew around one of the east/west poles to get through the } \\
\text { corridor. }\end{array}$ \\
\hline "Over" & $\begin{array}{l}\text { An individual that flew over the pole-crossing to get through the corridor. } \\
\text { This behavior was recorded whether there was a net or no net. }\end{array}$ \\
\hline "Through" & $\begin{array}{l}\text { An individual that flew through the middle of the roadway, between the two } \\
\text { poles in the pole-crossing, to travel through the corridor. This behavior was } \\
\text { only possible when there was no net in place or when individuals were small } \\
\text { enough to fit through the holes in the net. }\end{array}$ \\
\hline "Turn Around" & $\begin{array}{l}\text { An individual that flew up to or within } 1 \text { meter of the pole-crossing net and } \\
\text { turn around; barrier to movement through the corridor. The "turn around" } \\
\text { behavior indicated some impact of the net in determining the flight path. }\end{array}$ \\
\hline
\end{tabular}

\section{Statistical Analyses}

Non-parametric tests were used to analyze all datasets (non-normal, random, independent data). An open-source statistical software package, $R$, was used for all statistical analysis ( $R$ Development Team 2011). A Spearman's rank correlation coefficient was used to evaluate the tendency for condition variables (temperature, wind, relative humidity) to vary together with flight height in the middle of the pole-crossings. Visual analysis of flight height in the middle of the pole-crossings by location showed similar median values, thus location was not used as a variable in the analyses. A Wilcoxon rank sum test with continuity correction was used to compare difference in mean flight height compared to treatment (net vs. no net). A Fisher Exact Test was used to compare differences in behavior between treatments (net vs. no net) because of the low sample numbers. A Pearson's chi-square test with Yates' correction was used to evaluate the frequency distribution of flight path behavior in the connectivity analysis.

\section{Results}

Neither temperature $(p=0.55)$, wind $(p=0.25)$, nor relative humidity $(p=0.23)$ significantly covaried with flight height (table 2).

by Rebecca Jalene Littlejohn

Connecting habitat across roads 
Table 2: Mean, median, minimum and maximum values for weather conditions across all trials

\begin{tabular}{|l|r|r|r|}
\hline & Temp & Wind & RelHum \\
\hline Min & 18.0 & 0 & 26.8 \\
\hline Median & 23.7 & 0.5 & 33.2 \\
\hline Mean & 24.21 & 0.6 & 35.6 \\
\hline Max & 31.2 & 2.5 & 65.7 \\
\hline
\end{tabular}

The nets as a guiding barrier in this study posed no significant reduction in connectivity within the corridor $\left(\chi^{2}=0.98, n=114, p=0.32\right)($ fig 5$)$.

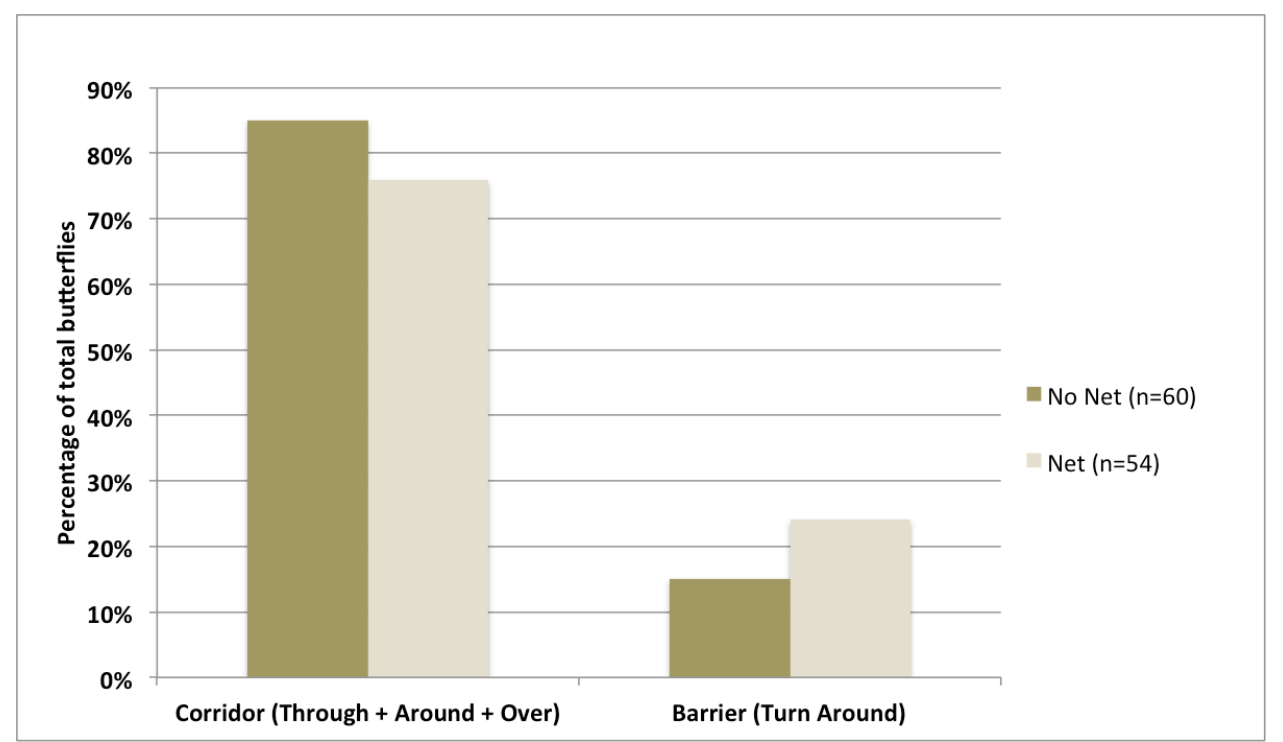

Figure 5: Percentage of individual butterflies that were able to travel the corridor (behaviors: through, around, over) vs. those that did not travel the corridor (behavior: turn around).

When butterflies flew over, around, or through the pole crossings, significantly more individual butterflies landed on the roadway between the pole-crossings when a net was in place (24\%) than when there was no net $(8 \% ; n=92, p=0.04$; fig 6$)$. However, for these same butterflies that traveled the corridor (over, around, or through the pole-crossings) no significant difference in flight height between the pole crossings was found between the treatments with a net (median height $=0.3 \mathrm{~m}<1.0 \mathrm{~m}<1.5 \mathrm{~m})$ and those without a net (median height $=0.5 \mathrm{~m}<\mathbf{0 . 8 m}<$ 1.0m; $\mathrm{W}=985, \mathrm{n}=92, \mathrm{p}=0.63)$. 


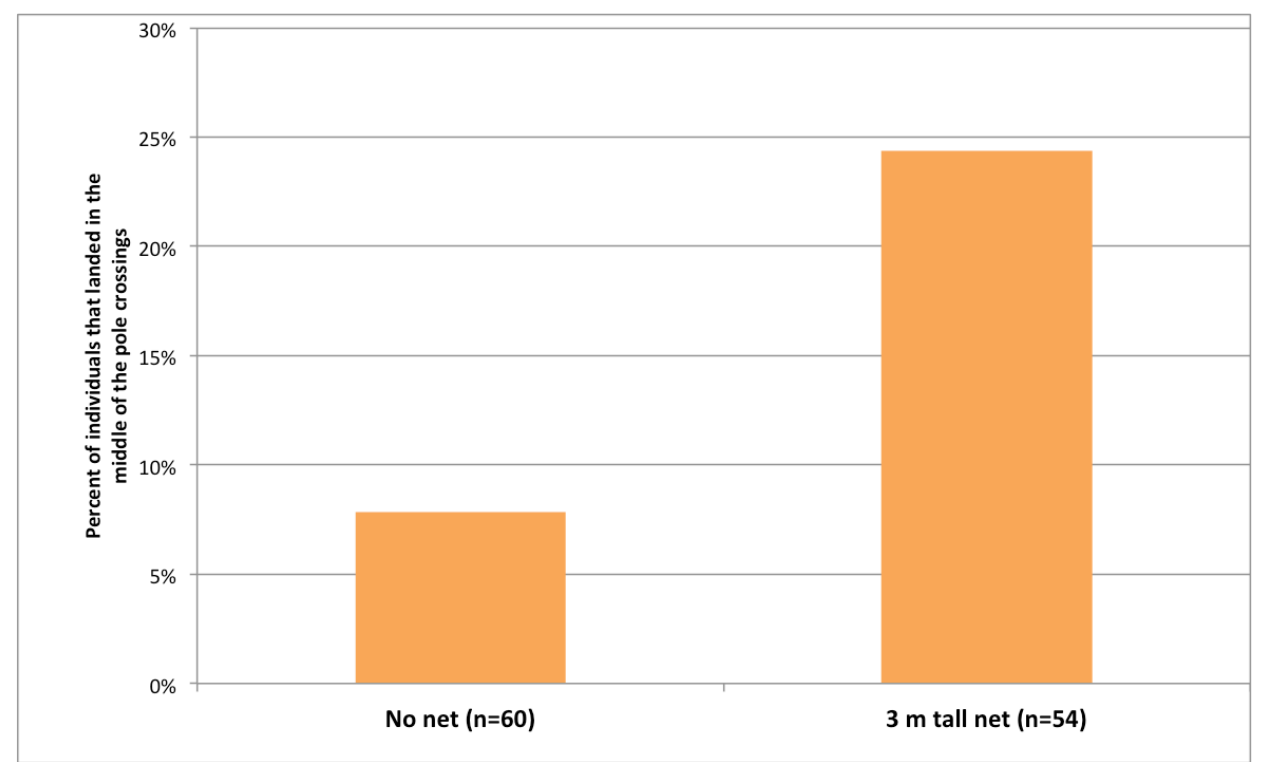

Figure 6: Percentage of individual butterflies that landed in the middle of the two pole-crossings. Comparison of treatments with a net vs. no net for all butterflies that flew through, around, or over.

Four flight behaviors were observed during the course of the study: "through", "around", "over" and "turn around" (tables $1 \& 2$ ). The predominant flight path behavior when there was a net in place was "around" $(54 \%, n=54)$, while the predominant behavior with no net was "through" $(58 \%, n=60 ; p<0.01 ;$ table 3$)$.

Table 3: Frequency of observed flight path behaviors, comparing between treatments with a net and no net.

\begin{tabular}{|c|c|c|c|c|}
\hline & \multicolumn{2}{|c|}{ No net $(n=60)$} & \multicolumn{2}{|c|}{$3 \mathrm{~m}$ tall net $(n=54)$} \\
\hline Behavior & NumObs & PercentTot & NumObs & PercentTot \\
\hline Through & 35 & $58 \%$ & 2 & $4 \%$ \\
\hline Around & 16 & $27 \%$ & 29 & $54 \%$ \\
\hline Over & 0 & $0 \%$ & 10 & $19 \%$ \\
\hline TurnAround & 9 & $15 \%$ & 13 & $24 \%$ \\
\hline & 60 & $100 \%$ & 54 & $100 \%$ \\
\hline
\end{tabular}


No individuals flew at a height of 3 meters or greater over both pole-crossings, regardless of the treatment (table 4$)$. One individual $(2 \%, n=60)$ flew at a safe height $(>2.5 \mathrm{~m})$ over both polecrossings during treatments with no net, and four individuals $(7 \%, \mathrm{n}=54)$ flew at a safe height during treatments with a net (table 4).

Table 4: Number of individuals and percent of total butterflies that crossed both pole-crossings at a safe height $(>2.5 \mathrm{~m})$

\begin{tabular}{|l|r|r|r|r|r|}
\hline \multicolumn{5}{|c|}{ Individuals that crossed both pole crossings at a safe height } \\
\hline & \multicolumn{2}{|c|}{ No net $(\mathbf{n}=60)$} & & \multicolumn{2}{|c|}{$\begin{array}{c}3 \text { m tall net } \\
(\mathbf{n}=54)\end{array}$} \\
\hline$\geq 3 \mathrm{~m}$ & 0 & 0 & 0 & $0 \%$ \\
\hline$\geq 2.5 \mathrm{~m}$ & 1 & $2 \%$ & 4 & $7 \%$ \\
\hline
\end{tabular}

\section{Discussion}

\section{Connectivity}

The first consideration of management strategies, such as guiding barriers, should be the impact that the strategy may have on connectivity. The goal is to increase connectivity between habitat resources, maximizing gene flow and resource use across the habitat, while minimizing road mortality. Twenty-two percent of observations from paired meadow and road plots were in road plots (Zielin 2010), suggesting that the management of connectivity across the highway is an important part of management for S. z. hippolyta. While flight behavior changed when a net was in place during this study's treatments, results showed no significant decrease in connectivity. Butterflies were still able to travel the corridor by flying over or around the net in their flight path. This suggests that vegetative guiding barriers along Highway 101 at Rock Creek may not be barriers to movement across the road. Differences in topography, location, and behavior that may naturally occur between these different isolated populations should be considered when making decisions about mitigation. However, the conclusion from this study 
at Mt. Hebo supports previous observations of Rock Creek -Big Creek individuals that S. z. hippolyta will fly over or around natural barriers they approach in their habitat, including tall vegetation, trees, and the road (Bennett 2010; Zielin 2010).

\section{Flight Behavior \& Flight Height}

This study confirmed previous field observations that average flight height of $S$. z. hippolyta is around one meter from the ground (Zielin 2010). The goal of vegetative guiding barriers is to increase the average flight height of individuals across the road to a height that exceeds most passing traffic. Previous research suggests that flight height of S. z. hippolyta increases relative to the height of vegetation adjacent to the highway, with observations ranging between $2 \mathrm{~m}-7 \mathrm{~m}$ (Bennett 2010, Zielin 2010). However, in this study, no significant difference was observed in flight height of butterflies flying over or around a guiding barrier when there was a net versus when there was not a net in place. Moreover, butterflies may not fly at a safe height over the roadway but instead fly down into the road or land on the road surface. This study found that sampled S. z. hippolyta individuals were three times more likely to fly down to the road surface after flying over a guiding barrier than individuals that flew at a lower height without a guiding barrier in their path. No individuals flew at a height greater than three meters over both polecrossings. While there is no research to suggest the flight height that is the most successful "safe" flight height for S. z. hippolyta, 2.5 meters may be a good estimate for average vehicle height. Only $7 \%$ or less of all individuals that traveled the corridor flew at a safe height $(>2.5$ meters) over both pole-crossings.

Of the four flight behaviors observed in this study (table $1 \& 2$ ), the predominant flight behavior when there was a net in place was "around" $(54 \%, n=54$; table 3$)$. The nets in this study spanned the sunniest parts of the corridor, but did not completely block the butterflies' flight path. This setup mimics field conditions where there may be gaps in vegetation, but does not 
mimic the final mitigation solution in which establishment of vegetative hedgerows or other guiding barriers would undoubtedly cover a distance longer than 7 meters. There is some evidence that $S$. z. hippolyta is currently utilizing a least cost path across the highway where vegetation is lowest (Bennett 2010), suggesting that individuals crossing the highway may use gaps in vegetation first ("around" behavior) before flying over vegetation, if this option is available within a short distance. Anecdotal observations of Rock Creek-Big Creek individuals suggest that if guiding barriers are installed to span the distance between natural vegetation without breaks, the butterflies will fly over the barrier rather than finding a path around or flying through nets or vegetation (M. Bray 2012, unpublished observations). Further, individuals may be deterred from flying over a guiding barrier in windy conditions and remain on one side of the guiding barriers depending on the local topography (M. Bray 2012, unpublished observations). If this is the case, guiding barriers could be used as a means to retain butterflies on the east side of the highway in restored meadows, rather than as a means to encourage increased flight height over the highway. More information is needed regarding the behavior of Rock Creek-Big Creek individuals in response to guiding barriers.

\section{Study Design and Implementation}

It is important to note some unavoidable issues with this study and design that should be considered in the application of these results. First, these data were collected in an area lacking the influence of traffic. It has been observed that butterflies flying up to the highway at Rock Creek when there is passing traffic may return back to the point of entry rather than crossing the road and others that do enter the roadway may get caught up in the wind vortex of a passing car influencing flight behavior and flight height (Bennett 2010; Zielin 2010). In addition, butterflies may decide to turn around upon approaching unfavorable conditions created by a vehicle in the 
roadway (Bennett 2010). Thus, observed behavior may vary between the experimental study and individuals crossing the highway at Rock Creek-Big Creek.

The results of this study are based on an experimental setup that was designed to mimic vegetative guiding barriers (3-meter nets) and the length of the critical flight path across a road (8-meter section in between pole-crossings). Structural differences in vegetation, in comparison to the nets used in this study, may provide some differences in results. The nets were similar to vegetation in that they do not create a full barrier to movement for $S$. $z$. hippolyta individuals, but are different in that they do not block sunlight or create shade as vegetation would and may not have been as visible from a distance. Although, un-tested observations of $S$. z. hippolyta during pilot tests and in Zielin's 2010 study documented similarities in flight path behavior between individuals approaching vegetation and the nets in this study. It was observed that $S . z$. hippolyta flight behavior did not change height or direction until the individual was relatively close to the object it would fly over or around. This similarity suggests that the results from this study provide conclusions that can be utilized to address management options.

Experimental data collection was not possible outside of the sunniest hours of the day due to shade patches in the corridor that influenced flight paths and frequencies. Pilot tests revealed that individuals traveled most commonly in the sunniest portions of the corridor. While part of the southern end of the corridor was sunny for most of the day, this corridor area was very wide with more variable topography, which would have decreased the effectiveness of the nets in the study design and thus was excluded from the study area. The 80-meters of corridor area that were used in the study increased the capacity of the nets to cover the sunniest portions of the roadway and verges, exhibited relatively consistent topography, and were surrounded by a treeline that provided relatively less opportunity for the butterflies to travel "around" the net. This treeline decreased the availability of time with consistent sun on the roadway, decreasing by Rebecca Jalene Littlejohn Connecting habitat across roads 
sampling time. Thus, fewer trials were conducted than would have been optimal. The trials in this study were conducted during optimal flight conditions. Weather conditions at the Rock Creek site may provide different circumstances that influence behavior and/or frequency of flight across the highway.

Furthermore, it is difficult for a novice to identify between S. z. hippolyta and a similarly looking Hydaspe butterfly, especially during flight. Thus, it is unclear how many of the sampled observations are Hydaspe spp. and not S. z. hippolyta. It is possible that results would be similar, but it was impossible to separate these observations within this study.

\section{Conclusion}

This study provides a good foundation of data to suggest that vegetative guiding barriers may not be the best mitigative solution to increasing connectivity between cross-highway habitat resources at Rock Creek and decreasing road mortality of S. z. hippolyta. S. z. hippolyta individuals are not inhibited from flying over tall vegetation or other guiding barriers, but there is some question about whether guiding barriers will increase safe flight height over the road or rather increase the number of individuals that fly down to the roadway. Based on the results of this study, it is recommended that land managers do not move forward with planting vegetative hedgerows with the goal of increasing flight height over the highway as part of the management and recovery of S. z. hippolyta at Rock Creek-Big Creek. Instead, management efforts would be best focused on restoration on the east side of the highway away from the road and verges to decrease the attraction to cross the road and increase habitat resource capacity to support the Rock Creek - Big Creek population. Anecdotal field observations have suggested that it may be possible that guiding barriers will influence $S$. z. hippolyta to stay on one side of the highway rather than flying around or over the guiding barrier depending on wind conditions and topography at Rock Creek-Big Creek. In this case, butterflies could be encouraged to remain in 
restored east-side meadows. Additional testing at Rock Creek-Big Creek is necessary to know whether guiding barriers would be effective in this way.

by Rebecca Jalene Littlejohn Connecting habitat across roads 


\title{
Chapter 2: Vegetation height along Highway 101 at Rock Creek, Big Creek and nearby management areas in the Siuslaw National Forest
}

\author{
Abstract \\ Human-altered landscapes provide unique challenges for wildlife movement between habitat \\ resources. Spatial data can be used to analyze habitat features and wildlife habitat-use \\ patterns to assist with restoration, mitigation, and recovery efforts such as those for the \\ threatened Oregon silverspot butterfly (Speyeria zerene hippolyta). S. z. hippolyta is impacted \\ by a two-lane highway that bisects habitat patches along the Oregon coast. S. z. hippolyta has \\ been observed in previous studies to cross the highway primarily at five to ten locations. Light \\ Detection and Ranging (LiDAR) canopy height data were used to assess vegetation height \\ adjacent to known crossing locations and compared to known larval host plant availability (Viola \\ adunca). S. z. hippolyta is found to cross at locations that are adjacent to significantly lower \\ vegetation than other areas along the highway. Visual analysis supports this conclusion in \\ addition to travel between densely located habitat resources. Management recommendations \\ include increasing habitat restoration on the east side of the highway, reducing habitat \\ resources near the road, and maintaining habitat connectivity between meadows on the east \\ side. Spatial patterns and data analysis are useful for assessing mitigation efforts to assist the \\ recovery of S. z. hippolyta and other species.
}

\section{Introduction}

Human-altered landscapes provide unique challenges for wildlife species to travel between habitat patches (Fahrig 2007; Carr and Fahrig 2001). Roads and highways trigger numerous direct and indirect impacts on wildlife (Coffin 2007; R. Forman and Alexander 1998), often decreasing movement across habitat, changing movement behavior, or providing a barrier to movement (Glista, DeVault, and DeWoody 2009; Jacobson 2005; Kintsch and Cramer 2011; 
Bank et al. 2002, Metro 2010). The Oregon silverspot butterfly (Speyeria zerene hippolyta) is a threatened species that is impacted by a two-lane highway (Highway 101) that bisects habitat resources at a site on the Oregon coast, Rock Creek-Big Creek. Previous research suggests that the highway is not a barrier to movement for the species (Bennett 2010; Zielin 2010), yet there is some concern about the impact of vehicle-caused mortality on the viability of the small, fragile population (USFWS 2001). Consequently, land managers are considering management strategies that will decrease road mortality.

One such management strategy is to establish vegetative guiding barriers along both sides of the highway where S. z. hippolyta is known to cross between habitat resources. Previous observations suggest that the flight height of S. z. hippolyta in the road is influenced by the height of adjacent vegetation (Zielin 2010; Bennett 2010). The goal of installing guiding barriers is to modify the flight height of $S$. $z$. hippolyta, encouraging an increased flight height that exceeds most passing traffic. Previous research suggests that S. z. hippolyta crosses the highway in areas of low vegetation (Bennett 2010), which aligns with the theory that animals in both natural and human-altered landscapes will follow the least cost path between habitat resources (Fahrig 2007; Sawyer, Epps, and Brashares 2011). This study seeks to collect information from previous studies about the locations of S. z. hippolyta highway crossings and compare to adjacent vegetation height and habitat resource availability to look for patterns in distribution at Rock Creek-Big Creek as well as at nearby restoration sites.

\section{Study Objectives}

1. Identify the most common S. z. hippolyta highway crossings as documented in previous studies and compare to adjacent vegetation height and habitat resource availability. Are S. z. hippolyta individuals crossing the highway at locations where there is significantly 
lower vegetation? Are S. z. hippolyta individuals crossing the highway at locations where there are densely located habitat resources?

2. Spatially analyze the vegetation height along Highway 101 near the Rock Creek-Big Creek and Bray Point sites where land managers are currently restoring S. z. hippolyta butterfly habitat. Compare methods of assessing vegetation height for future restoration and management.

\section{Hypothesis}

S. z. hippolyta individuals are crossing the highway at locations with significantly lower vegetation than surrounding areas along the highway and between densely located habitat resources.

\section{Methods}

\section{Study Site}

The study site is located along Highway 101 south of Yachats on central Oregon coast, specifically focused around the Rock Creek-Big Creek meadows in the Siuslaw National Forest and northern private and public lands along Highway 101 between sites where restoration is happening and S. z. hippolyta populations are known to occur (fig 8).

Table 5: Data used in spatial analysis, sources, and associated analyses

\begin{tabular}{|c|c|c|}
\hline Data & Source/Date & Analysis \\
\hline Highway & $\begin{array}{l}\text { Oregon Department of } \\
\text { Transportation (ODOT) } \\
\text { / gis.oregon.gov / 2009 }\end{array}$ & $\begin{array}{l}\text { Use highway line to mark the location } \\
\text { of the highway. Highway crossing } \\
\text { points were located on this line for } \\
\text { consistency. }\end{array}$ \\
\hline Land Ownership & BLM / gis.oregon.gov & $\begin{array}{l}\text { Visual analysis of land ownership } \\
\text { where restoration areas are located } \\
\text { and adjacent land near the highway }\end{array}$ \\
\hline $\begin{array}{l}\text { Rock Creek -Big } \\
\text { Creek \& Bray Point } \\
\text { Habitat - Violet } \\
\text { surveys }\end{array}$ & $\begin{array}{l}\text { J.M. Patterson / U.S. } \\
\text { Forest Service (USFS) } \\
2011\end{array}$ & $\begin{array}{l}\text { Identify the location of restoration / } \\
\text { habitat sites and violet densities }\end{array}$ \\
\hline
\end{tabular}




\begin{tabular}{|l|l|l|}
\hline Data & Source/Date & Analysis \\
\hline $\begin{array}{l}\text { USFS restoration } \\
\text { sites }\end{array}$ & $\begin{array}{l}\text { U.S. Forest Service } \\
\text { information / created by } \\
\text { Jalene Littlejohn }\end{array}$ & $\begin{array}{l}\text { Identify the location of } \\
\text { restoration/habitat sites }\end{array}$ \\
\hline $\begin{array}{l}\text { Butterfly crossing } \\
\text { sections }\end{array}$ & $\begin{array}{l}\text { Zielin 2010, Bennett } \\
\text { 2010 Reports }\end{array}$ & $\begin{array}{l}\text { Identify the location of common S. } z . \\
\text { hippolyta highway crossings; buffered } \\
\text { crossing points to extract adjacent } \\
\text { vegetation height }\end{array}$ \\
\hline LiDAR canopy height & U.S. Forest Service & $\begin{array}{l}\text { Extract vegetation height values from } \\
\text { derived canopy height LiDAR data }\end{array}$ \\
\hline Base Map & Bing Maps & Aerial image for maps' base \\
\hline
\end{tabular}

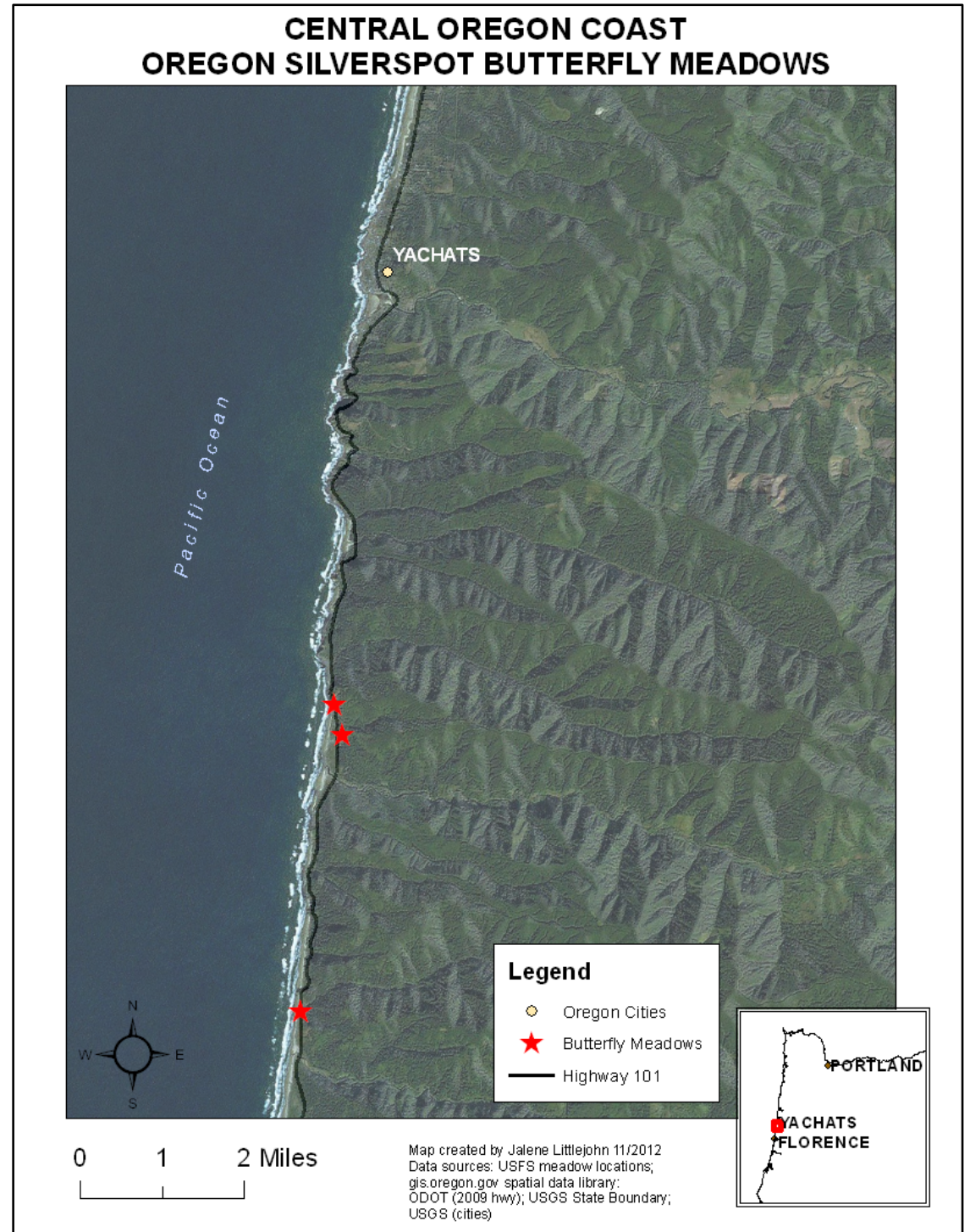

Figure 7: Site map of study area for spatial analysis of vegetation height along Highway 101 adjacent to S. z. hippolyta habitat. 


\section{Data Analysis}

To test the hypothesis that S. z. hippolyta most commonly crosses the highway at locations with significantly lower vegetation than other areas of the highway, ESRI Geographic Information System (GIS) tools (ArcMap, Spatial Analyst extension) were used to extract spatially relevant vegetation data and export data values to compute statistical analysis in an open-source statistical software package, R (R Development Team, 2011). A study area was created by clipping the highway line to just outside of the Rock Creek-Big Creek meadows as delineated by GPS points from a 2011 survey (M. Patterson 2011). Five highway crossing location points were digitized from each of two previous studies (Zielin 2010; Bennett 2010). Points were digitized on the highway line for consistency. Known crossing points were buffered $(20 \mathrm{~m}$ buffer). Zielin and Bennett data were extracted and analyzed separately as the studies did not utilize the same methods. Random points $(n=30)$ were generated along the highway line within the study area using a tool in ArcMap and buffered (20m buffer). Buffer size was created to accommodate the road $(\sim 8 m)+$ verge (variable width) + adjacent vegetation just outside of the verge (variable width).

Vegetation height data (LiDAR derived canopy height raster) was extracted from the $20 \mathrm{~m}$ buffers around known crossing locations and random points. Additionally, all vegetation height data from a 20-meter buffered area around the highway line in the study area was extracted. The extracted raster data was converted to points, and exported to data tables for analysis in $\mathrm{R}$.

In $\mathrm{R}$, vegetation height statistics were analyzed visually and statistically. Four datasets were examined: 1) Vegetation height around 5 crossing points from the Zielin (2009) study; 2) Vegetation height around 4 crossing points from the Bennett (2010) study (two of the buffered points overlapped, thus were aggregated into one crossing area); 3) Vegetation height around 
30 randomly generated points within the study area; and 4) Vegetation height from the full study area. Mean vegetation height was compared between known crossing locations and random datasets using a non-parametric Wilcoxon rank sum test with no correction necessary due to the large sample size.

To spatially analyze vegetation height along the highway corridor, both along areas with known crossing locations and other areas where restoration is happening, ArcMap was used to create maps of vegetation height from LiDAR derived canopy height (measured in feet) for visual analysis. The vegetation height raster data is extracted and displayed within a 40 -meter buffer on each side of the highway. Vegetation height is classified into four unique classes (fig 9): grey $=0-0.5$ feet or $\sim 0 \mathrm{~m}$; yellow $=0.5-3$ feet or $\sim 1 \mathrm{~m}$; green $=3-9$ feet or $\sim 2-3 \mathrm{~m}$; and blue $=9-$ 188 feet or $\sim 3+m$. The figures use estimates in meters for ease and to track the research methods in Chapter 1 in which a 3-meter guiding barrier was used in analysis. Additional visual analyses were conducted using 2011 violet count data for survey points in meadows at both Rock Creek-Big Creek and Bray Point. Survey points were converted to raster layers at each site and classified into four unique classes (fig 10 \& 11) from light to dark purple: $0,1-10,11-60$, and 61-154 violet plants.

\section{Results}

There was a significant difference between the mean vegetation height adjacent to known $S$. $z$. hippolyta crossing points from the Bennett study (2010) (mean height: $0.63 \mathrm{ft}+/-0.008 \mathrm{ft}$ ) and randomly generated points and full study area along the highway in the Rock Creek study area (mean height: $1.98 \mathrm{ft}+/-0.01 \mathrm{ft} ; \mathrm{p}<0.01$; fig 8). The known crossing points from the Zielin study (data collected in 2009) had a surrounding mean vegetation height of $1.75 \mathrm{ft}+/-0.002 \mathrm{ft}$, which varied significantly from the full study area's vegetation height $(p<0.01)$ but did not vary 
significantly from the vegetation height surrounding the randomly generated points $(p=0.10$; fig 8).

Visual analysis of vegetation height along the highway (fig 13) shows that S. z. hippolyta crossing points are located in areas of low vegetation and most of the points are generally located in between areas of densely located resources ( $V$. adunca).

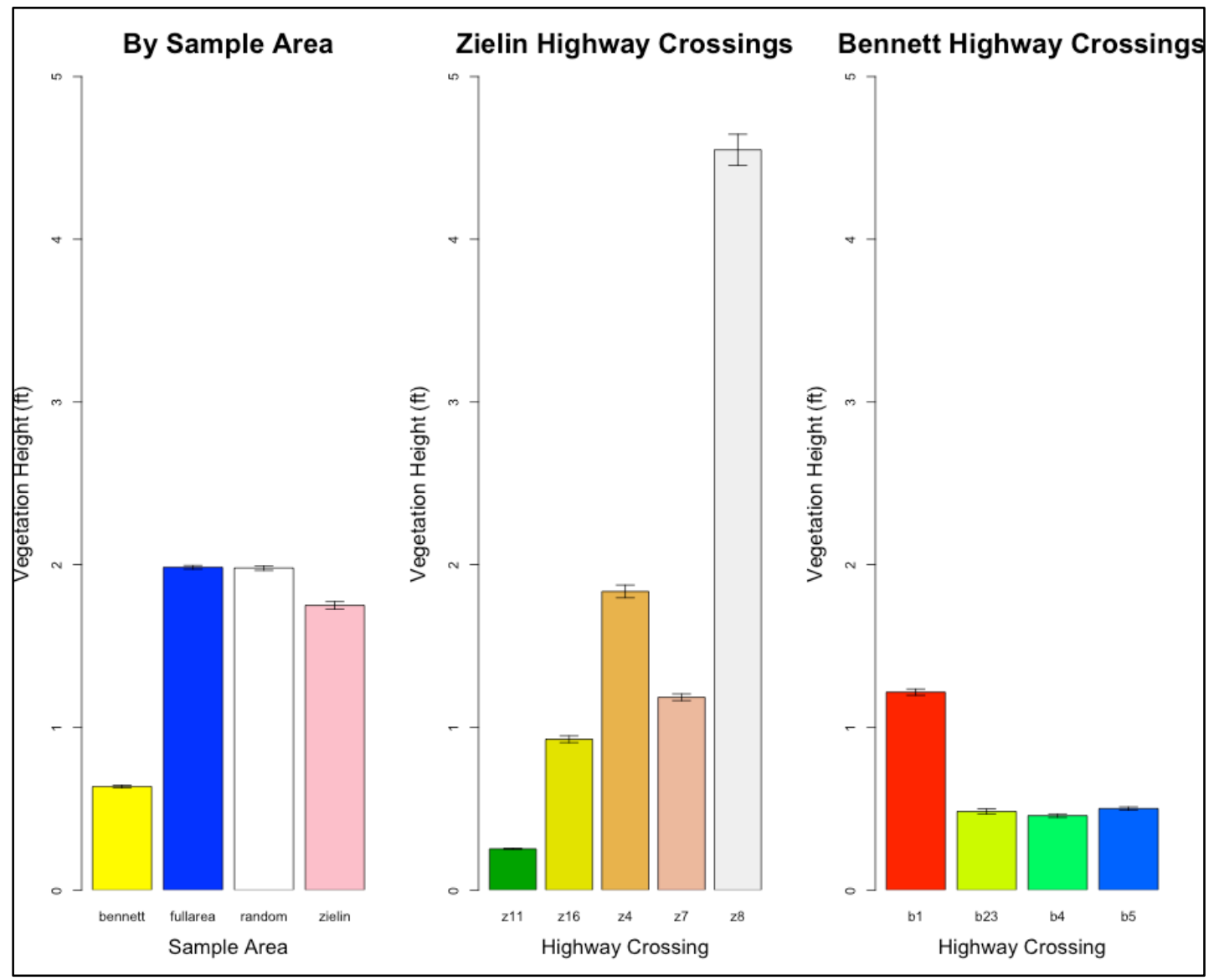

Figure 8: mean vegetation height within aggregated sample areas (left) and between individual highway crossing points from the Zielin (2009) study (middle) and Bennett study (2010; right). 


\section{Known Butterfly Highway Crossings Rock Creek-Big Creek}

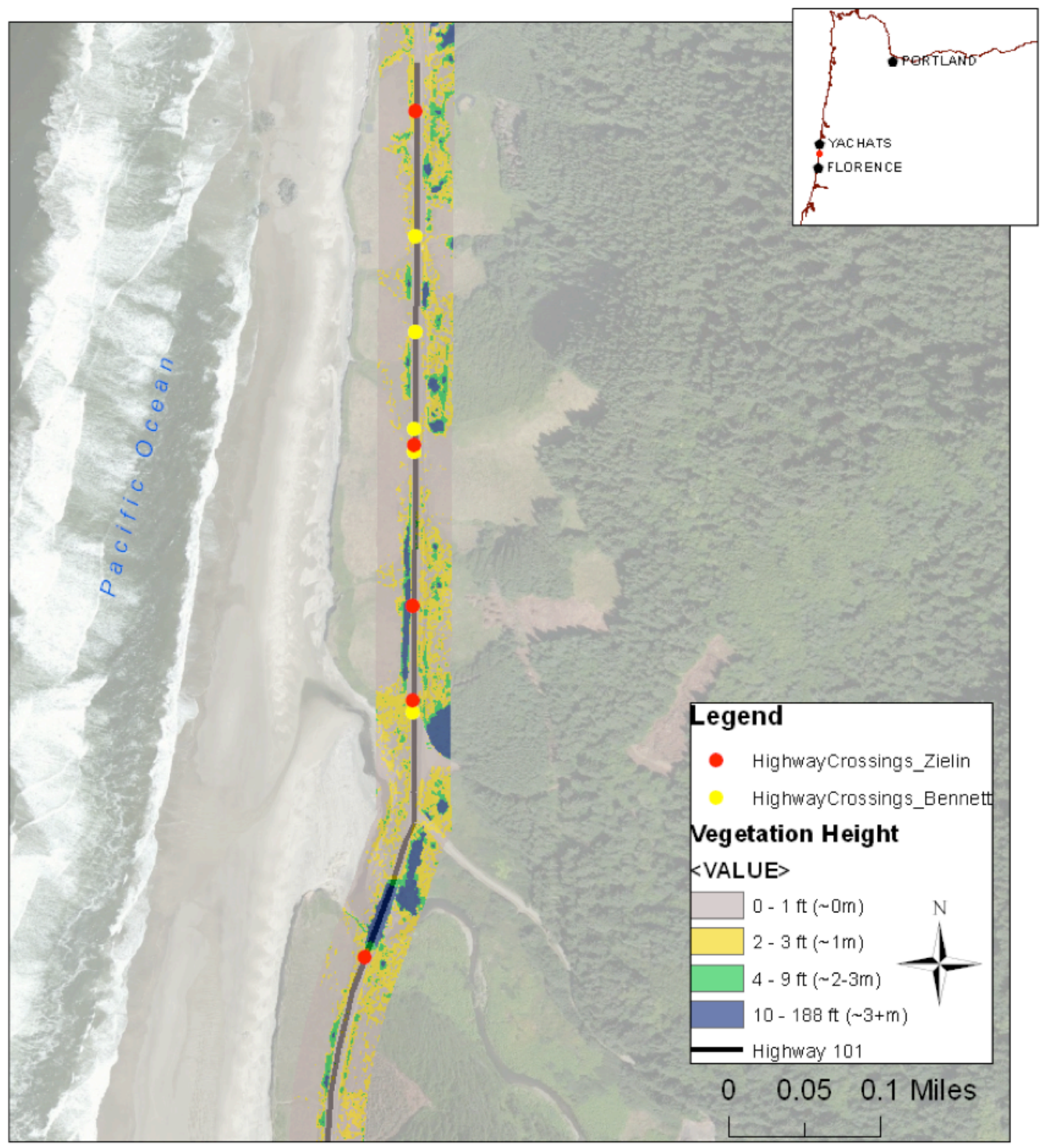

Map Created Nowember, 2012

Jalene Littlejohn

Data Sources: Bing maps, highway crossing points from previous studies: Bennett 2010, Zie lin 2010

ODOT highway 2009, USFS Vegetation height (LiDAR)

BLM cities \& state boundary

Figure 9: Map of Rock Creek Meadows, managed by the USFS Siuslaw National Forest. Points indicate the highway crossing points from Bennett 2010 and Zielin 2010. Vegetation height is classified in meters within a 40-meter buffer on each side of the highway. 


\section{Known Butterfly Highway Crossing Points \& Violet Density Rock Creek - Big Creek}

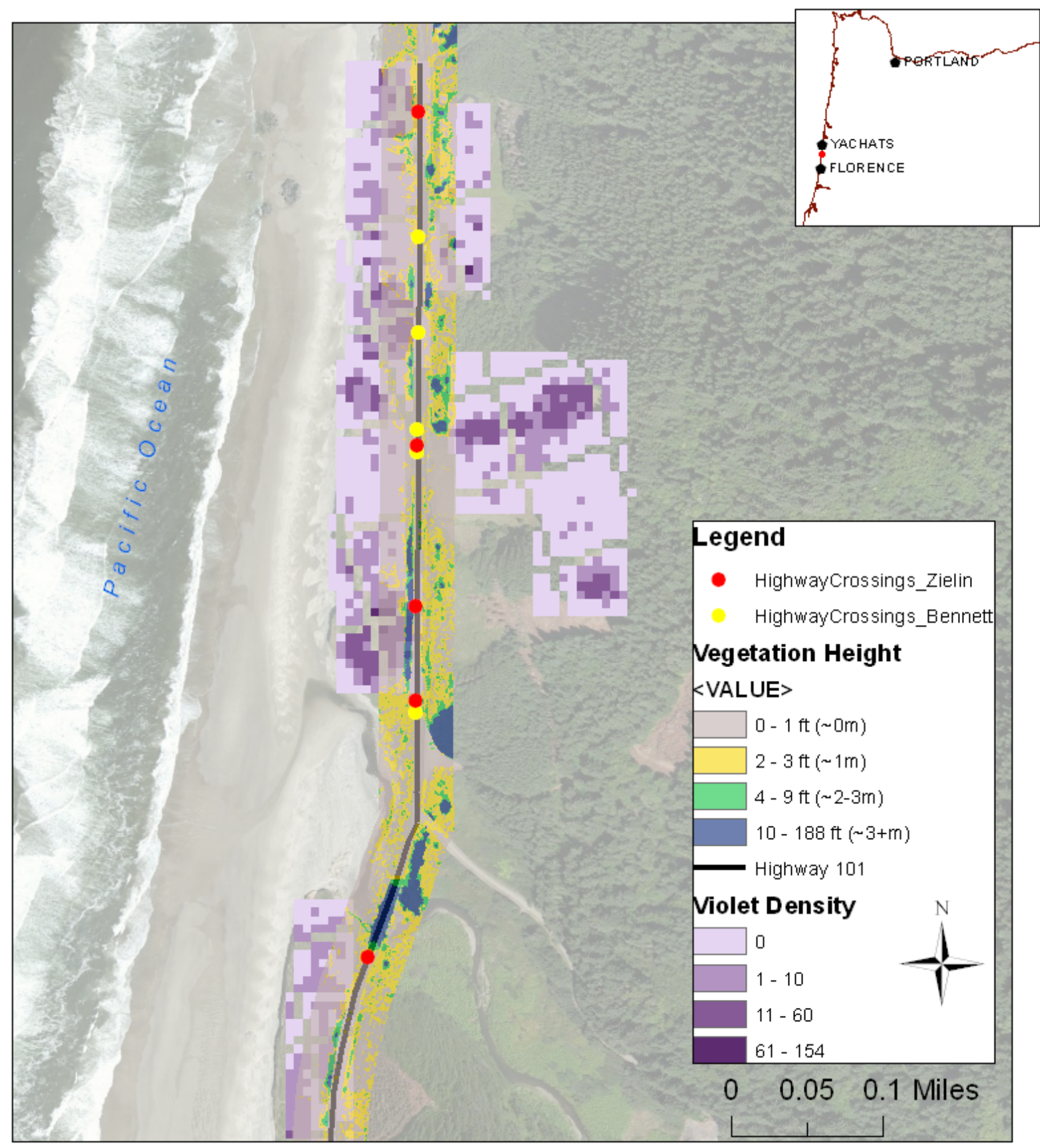

Map Created November, 2012

Jalene Littlejohn

Data Sources: Bing maps, highway crossing points from previous studies: Bennett 2010, Zielin 2010

ODOT highway 2009, USFS Vegetation height (LiDAR)

BLM cities \& state boundary, USF S violet survey 2011

Figure 10: map of Rock Creek-Big Creek site identifying violet densities, highway crossing points, and vegetation height adjacent to the highway. Visual analysis shows that most of the crossing points are located in areas of low vegetation and between densely located habitat resources (violets).

by Rebecca Jalene Littlejohn

Connecting habitat across roads 


\section{Discussion}

Results confirm what is expected from a species that is utilizing a least cost path between habitat resources; S. z. hippolyta is crossing the highway at locations where adjacent vegetation is significantly lower than other areas and between areas where violets (a critical habitat resource) are densely located. Additional variables such as nectar resources, wind or weather, topography, landscape characteristics (Glista, DeVault, and DeWoody 2009), and species interactions may play a role in determining the least cost path for $S$. z. hippolyta. Other animal species, including other butterflies as well as mammals, have been known to utilize certain landscape types as corridors more than others such as using grassy areas or preferring dirt roads over gravel roads (Sutcliffe and Thomas 1996; Brock and Kelt 2004), suggesting that the whole matrix is important, not just the crossing point (Sutcliffe and Thomas 1996; Chardon, Adriaensen, and Matthysen 2003).

Figure 8 highlights the variation in vegetation height between the individual highway crossing areas. In particular, crossing point Z8 averages vegetation height of over four feet, while all other crossing points have a mean of less than two feet. The vegetation height data used in this analysis is derived from LiDAR data calculated by subtracting the bare earth value from the top canopy value. In areas where the road cut is deep, the vegetation may be relatively tall from root to canopy, but much shorter when measuring from the road surface. Crossing point Z8 may be representative of this type of error that can occur when utilizing LiDAR for vegetation analysis along a road. While the vegetation is actually taller in this area, butterflies may still be able to fly at a lower height over the road due to the relative height of the vegetation at the road surface. Field data collection is needed to confirm the vegetation height from the road surface at this crossing point. 
There are many organizations, agencies, and land managers that are playing an active role in restoration of habitat, research, and recovery planning for S. z. hippolyta. More spatial data are needed to ensure maximum practicality of using spatial analysis to aid in recovery planning such as: current and planned restoration activities, flight path behavior of S. z. hippolyta in between sites, and spatial locations of population change over time. For example, there are currently no spatial data regarding the presence of highway crossing points or travel paths at Bray Point or other restoration sites north of Rock Creek-Big Creek (fig 11). Land managers at the USDA Forest Service are restoring habitat areas on the east side of the highway at Bray Point and additional restoration locations just south of Bray Point. Additionally, the U.S. Fish \& Wildlife Service is partnering with the Nature Conservancy to implement Safe Harbor Agreements with private landowners near this area. Safe Harbor Agreements are voluntary agreements between the government agency and private landowners who are impacting threatened or endangered species. Currently, there are Safe Harbor agreements in place to enhance private yards for S. z. hippolyta habitat. Spatial data about the interaction and movement of S. z. hippolyta between these different sites, observations of potential use of the highway near these locations, and information about habitat restoration would make this analysis more robust. 


\section{VEGETATION HEIGHT ALONG HWY 101 BRAY POINT AND ADDITIONAL ACTIVE RESTORATION AREAS}

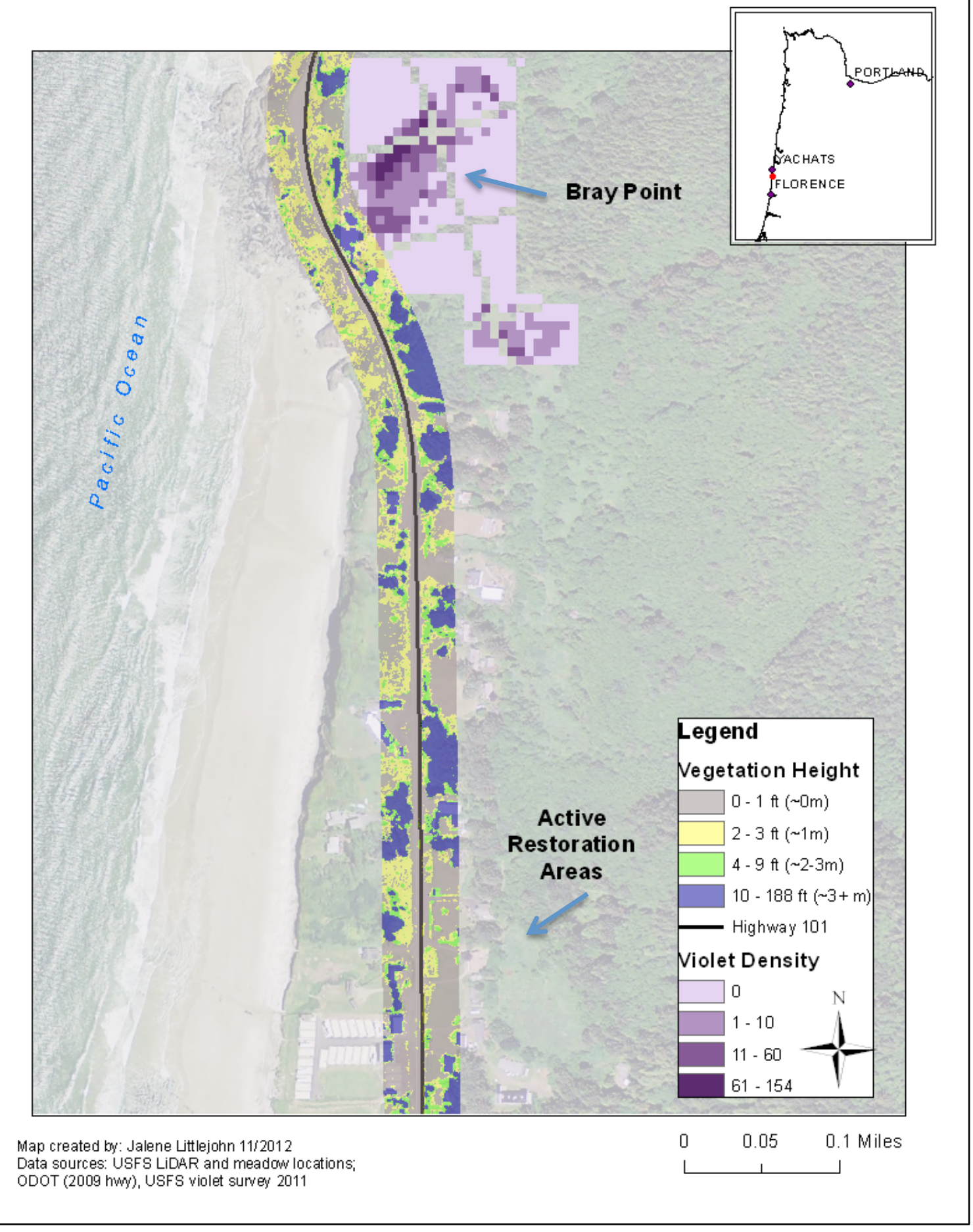

Figure 11: Map of Bray Point meadows, managed by the USFS Siuslaw National Forest. No highway crossing data are available for these sites. Vegetation height is classified in meters within a 40-meter buffer on each side of the highway. Violet count densities are highlighted in purple at the Bray Point site. No habitat data is available at the other restoration sites. 


\section{Conclusion}

S. z. hippolyta is likely crossing the highway at points where adjacent vegetation is lower than other areas along the highway and between areas of densely located habitat resources. This result is useful in assessing habitat use, highway crossing points, and mitigation efforts. If restoration efforts are focused on the east side of the highway, measures will need to be taken to encourage butterflies to stay on that side by providing more densely located habitat resources in the areas individuals are currently using and creating open corridors between meadows. This can be done at the two meadows on the east side at Rock Creek and between Bray Point and the new restoration areas/ Safe Harbor properties just south of Bray Point. It is recommended that more spatial data be compiled and tracked over time to aid in recovery efforts. 


\section{Next Steps \& Recommendations}

Overall, the results of this study suggest that $S$. z. hippolyta is crossing the highway in predictable locations of low adjacent vegetation and between densely located habitat resources such as Viola adunca. Based on the results of this study, the following management strategies are recommended to increase habitat connectivity and decrease road mortality for $S . z$. hippolyta:

\section{Reduce road dangers to S. z. hippolyta.}

a. Continue mowing the road verges along highway 101 at Rock Creek-Big Creek, especially in the areas where S. z. hippolyta is known to cross the highway. This management effort will reduce attraction to the roadside, may reduce use of the road, and may reduce road mortality. Continued monitoring is necessary to assess effectiveness of roadside mowing. Continue to record spatial data.

b. Do not plant hedgerows along the highway at this time with the goal to increase flight height over the road. More investigation is necessary to test the results of this study at Rock Creek-Big Creek before guiding barriers are installed. Results of this study suggest that tall vegetation or other guiding barriers along the roadway may not increase flight height over the road. Rather, guiding barriers may increase the instances in which individuals will fly down to the road surface. Additional studies may include analysis of increasing the length of guiding barriers and/or gaps within the length of the nets, testing different guiding barriers other than nets such that sun and shade are affected, or adding attractants to the top of the guiding barriers.

c. Investigate whether guiding barriers may provide a means for retaining butterflies on the east side of the highway, rather than crossing. This may be 
the case in specific locations where wind and topography currently affect the flight path of S. z. hippolyta individuals.

\section{Concentrate restoration efforts on the east side of the highway.}

a. The Rock Creek - Big Creek meadows currently comprise habitat resources on both sides of the highway, but restoration efforts should be focused on the east side of the highway where meadows are less-impacted by weather conditions. Continue restoring dense areas of habitat resources as far away from the highway as possible to keep the butterflies from flying into the road. Continued monitoring is needed to assess effectiveness of east side restoration and associated spatial populations shifts in habitat use and movement.

b. The Bray Point and nearby new restoration areas are located solely on the east side of the highway. Continue restoration efforts on this side of the highway as far away from the road as possible. Compilation of spatial data and baseline information about these sites is necessary, in addition to continued monitoring of habitat use, restoration success, and movement between restoration areas.

\section{Create open corridors between east side meadows.}

a. Results of this study suggest that S. z. hippolyta will utilize a least cost path when travelling between habitat resources. Thus, to keep individuals on the east side of the highway, continue maintenance of corridors for butterflies to travel between east side meadows at Rock Creek-Big Creek and between Bray Point and new restoration areas.

b. Spatial analysis may be helpful in planning for corridors. Information about least cost paths that butterflies are likely to use, or paths that are most efficient for restoration, may be generated from the LiDAR vegetation height data with additional information about current vegetation species composition (such as nectar plants) and S. z. hippolyta habitat use over time. 


\section{References}

Bank, Fred, C. Leroy Irwin, Gary Evink, Mary Gray, Susan Hagood, John Kinar, Alex Levy, et al. 2002. Wildlife Habitat Connectivity Across European Highways. Vol. 02. Alexandria, VA. doi:Report for the Federal Highway Administration.

Bennett, Victoria J. 2010. Addressing the Primary Threats That Jeopardize the Last Remaining Oregon Silverspot Butterfly (Speyeria Zerene Hippolyta) Populations. Corvallis, OR.

Benítez-López, Ana, Rob Alkemade, and Pita a. Verweij. 2010. "The Impacts of Roads and Other Infrastructure on Mammal and Bird Populations: A Meta-analysis." Biological Conservation 143 (6) (June): 1307-1316. doi:10.1016/j.biocon.2010.02.009. http://linkinghub.elsevier.com/retrieve/pii/S0006320710000480.

Brock, Rachel E., and Douglas A. Kelt. 2004. "Influence of Roads on the Endangered Stephens' Kangaroo Rat (Dipodomys Stephensi): Are Dirt and Gravel Roads Different?" Biological Conservation 118 (5): 633-640.

http://www.sciencedirect.com.proxy.lib.pdx.edu/science/article/pii/S0006320703004099.

Bruckmann, Sabrina V., Jochen Krauss, and Ingolf Steffan-Dewenter. 2010. "Plant and Butterfly Specialists Suffer from Fragmentation." Journal of Applied Ecology 47: 799-809.

Carr, L.W., and L. Fahrig. 2001. "Effect of Road Traffic on Two Amphibian Species of Differing Vagility." Conservation Biology 15: 1071-1078.

Chardon, J. Paul, Frank Adriaensen, and Erik Matthysen. 2003. "Incorporating Landscape Elements into a Connectivity Measure : a Case Study for the Speckled Wood Butterfly ( Pararge Aegeria L .)." Landscape Ecology 18: 561-573.

Coffin, Alisa W. 2007. "From Roadkill to Road Ecology: A Review of the Ecological Effects of Roads." Journal of Transport Geography 15 (5) (September): 396-406. doi:10.1016/j.jtrangeo.2006.11.006. http://linkinghub.elsevier.com/retrieve/pii/S0966692306001177.

Corlatti, Luca, Klaus Hackländer, and Fredy Frey-Roos. 2009. "Ability of Wildlife Overpasses to Provide Connectivity and Prevent Genetic Isolation." Conservation Biology: the Journal of the Society for Conservation Biology 23 (3) (June): 548-56. doi:10.1111/j.15231739.2008.01162.x. http://www.ncbi.nlm.nih.gov/pubmed/19210301.

Fahrig, Lenore. 2007. "Non-optimal Animal Movement in Human-altered Landscapes." Functional Ecology 21 (6) (December): 1003-1015. doi:10.1111/j.13652435.2007.01326.x. http://doi.wiley.com/10.1111/j.1365-2435.2007.01326.x.

Forman, Richard, and Lauren Alexander. 1998. "ROADS AND THEIR MAJOR ECOLOGICAL EFFECTS." Annual Review of Ecology and Systematics 29: 207-231 +C2.

Forman, Richard T. T. 2000. "Estimate of the Area Affected Ecologically by the Road System in the United States." Conservation Biology 14 (1) (February): 31-35. doi:10.1046/j.15231739.2000.99299.x. http://doi.wiley.com/10.1046/j.1523-1739.2000.99299.x.

by Rebecca Jalene Littlejohn

Connecting habitat across roads

Page 43

$12 / 11 / 12$ 
Glista, David J., Travis L. DeVault, and J. Andrew DeWoody. 2009. "A Review of Mitigation Measures for Reducing Wildlife Mortality on Roadways." Landscape and Urban Planning 91 (1) (May): 1-7. doi:10.1016/j.landurbplan.2008.11.001. http://linkinghub.elsevier.com/retrieve/pii/S0169204608001886.

Jackson, Scott D. 2000. "Overview of Transportation Impacts on Wildlife Movement and Populations." In Wildlife and Highways: Seeking Solutions to an Ecological and Socioeconomic Dilemma, ed. T.A. Messmer and West, 7-20.

Jacobson, Sandra L. 2005. Mitigation Measures for Highway-caused Impacts to Birds. doi:Gen. Tech. Rep. PSW-GTR-191.2005.

Kintsch, Julia, and Patricia Cramer. 2011. Permeability of Existing Structures for Terrestrial Wildlife : A Passage Assessment System. Olympia, WA. doi:Research Report No. WA-RD 777.1.

Munguira, M.L., and J.A. Thomas. 1992. "Use of Road Verges by Butterfly and Burnet Populations, and the Effect of Roads on Adult Dispersal and Mortality." Journal of Applied Ecology 29 (2): 316-329.

Patterson, J Micheal. 2010. Oregon Silverspot Fritillary Population Monitoring 2010 Flight Season. Vol. 30. Astoria, OR.

Rao, R Shyama Prasad, and M K Saptha Girish. 2007. "Road Kills : Assessing Insect Casualties Using Flagship Taxon.” Current Science 92 (6): 830-837.

Sawyer, Sarah C., Clinton W. Epps, and Justin S. Brashares. 2011. "Placing Linkages Among Fragmented Habitats: Do Least-cost Models Reflect How Animals Use Landscapes?" Journal of Applied Ecology 48 (3) (June 23): 668-678. doi:10.1111/j.13652664.2011.01970.x. http://doi.wiley.com/10.1111/j.1365-2664.2011.01970.x.

Sillero, Neftali. 2008. "Amphibian Mortality Levels on Spanish Country Roads: Descriptive and Spatial Analysis." Amphibia-Reptilia 29: 337-347.

Sutcliffe, Odette L, and Chris D Thomas. 1996. "Open Corridors Appear to Facilitate Dispersal by Ringlet Butterflies (Aphantopus Hyperantus) Between Woodland Clearings." Conservation Biology 10 (5): 1359-1365.

USFWS. 2001. Revised Recovery Plan for the Oregon Silverspot Butterfly (Speyeria Zerene Hippolyta). Portland, OR. http://www.fws.gov/pacific/ecoservices/endangered/recovery/silverspot/.

Zielin, S. 2010. "Exploring Mitigation Options to Reduce Vehicle-caused Mortality for the Oregon Silverspot Butterfly, Speyeria Zerene Hippolyta, Along Highway 101 at the Suislaw National Forest." Portland State University, Portland OR. 


\section{Appendices}

\section{Flight Height - additional figures}

Flight height data from chapter 1 by trial location. 6 trials were conducted at 6 randomly selected locations, two of which were the same location.

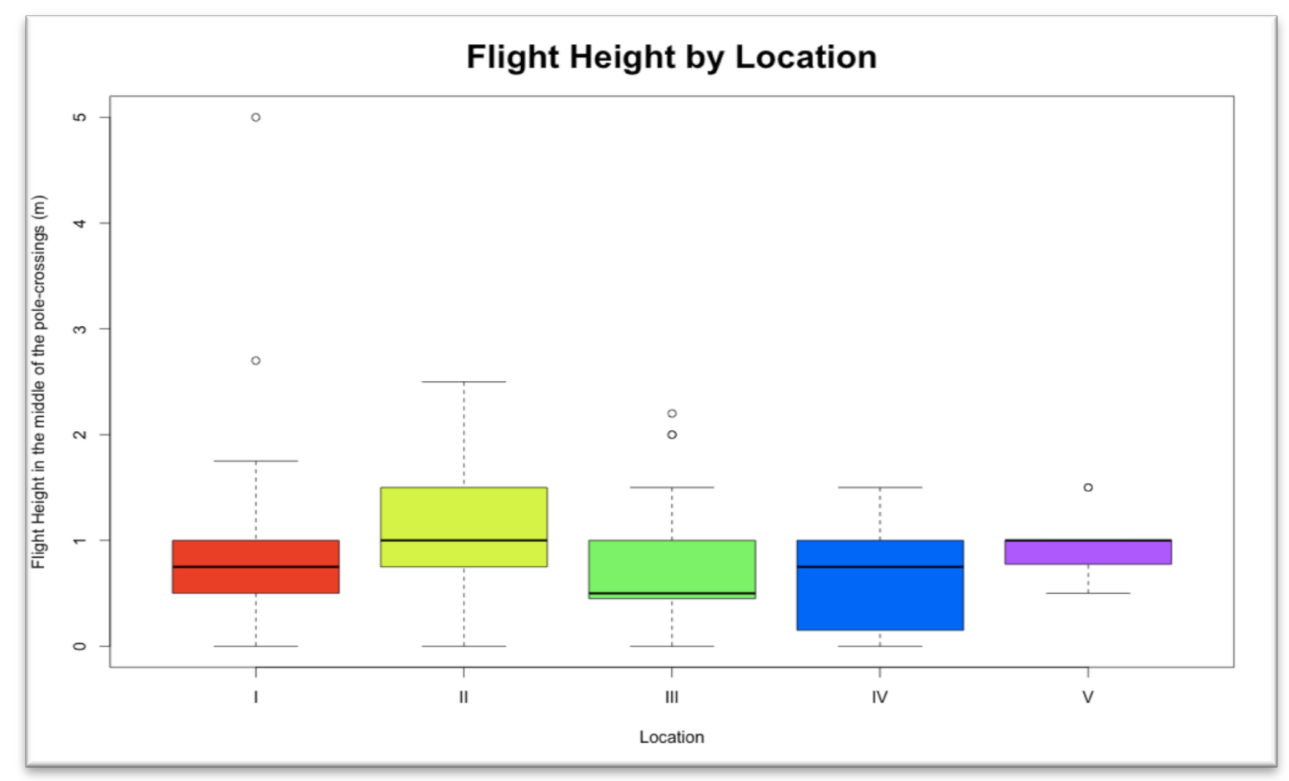

Figure 12: Flight height in the middle of the pole-crossings by location. Determined to be similar by visual analysis, thus all flight height data was pooled for statistical analysis.

Table 6: Flight height descriptive statistics by trial between treatments (net vs. no net)

\begin{tabular}{|c|c|c|c|c|c|c|c|}
\hline \multirow{6}{*}{ Net } & Trial & Median & Mean & 1st quartile & 3rd quartile & Std Dev & $\mathrm{n}$ \\
\hline & I & 0.88 & 1.20 & 0.13 & 1.00 & 1.56 & 10 \\
\hline & II & 1.00 & 1.21 & 0.50 & 2.00 & 1.04 & 7 \\
\hline & III & 1.00 & 0.92 & 0.50 & 1.50 & 0.73 & 17 \\
\hline & IV & 0.30 & 0.43 & 0.15 & 0.65 & 0.51 & 3 \\
\hline & $\mathrm{V}$ & 1.00 & 1.00 & 0.88 & 1.13 & 0.41 & 4 \\
\hline \multirow{6}{*}{ No Net } & & & & & & & \\
\hline & 1 & 0.70 & 0.77 & 0.50 & 1.00 & 0.45 & 11 \\
\hline & II & 1.00 & 1.01 & 0.75 & 1.38 & 0.68 & 15 \\
\hline & III & 0.50 & 0.63 & 0.43 & 1.00 & 0.30 & 14 \\
\hline & IV & 0.88 & 0.81 & 0.56 & 1.13 & 0.63 & 4 \\
\hline & $\mathrm{V}$ & 1.00 & 0.97 & 0.78 & 1.00 & 0.26 & 7 \\
\hline
\end{tabular}

by Rebecca Jalene Littlejohn 
Table 7: Wilcoxon rank sum test results for flight height between treatments (net vs. no net) for each trial

\begin{tabular}{|l|r|r|}
\hline Trial & W & p-value \\
\hline I & 56.5 & 0.94 \\
\hline II & 60.0 & 0.62 \\
\hline III & 147.0 & 0.26 \\
\hline IV & 4.0 & 0.59 \\
\hline V & 15.5 & 0.84 \\
\hline
\end{tabular}

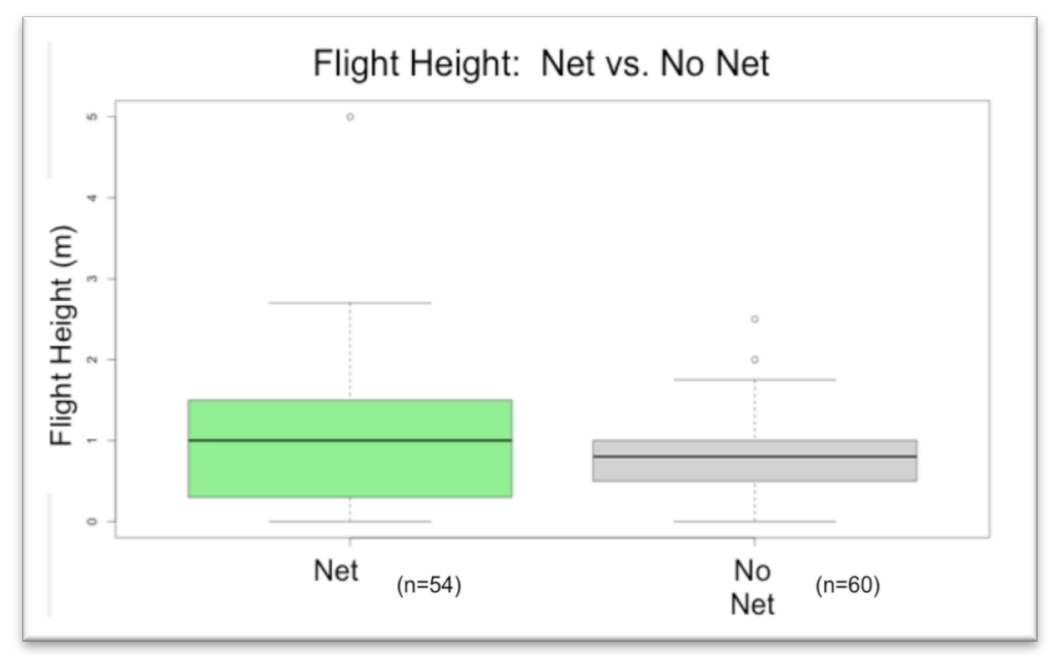

Figure 13: Range of flight height (in meters) of individuals, comparing treatments with a net vs. no net

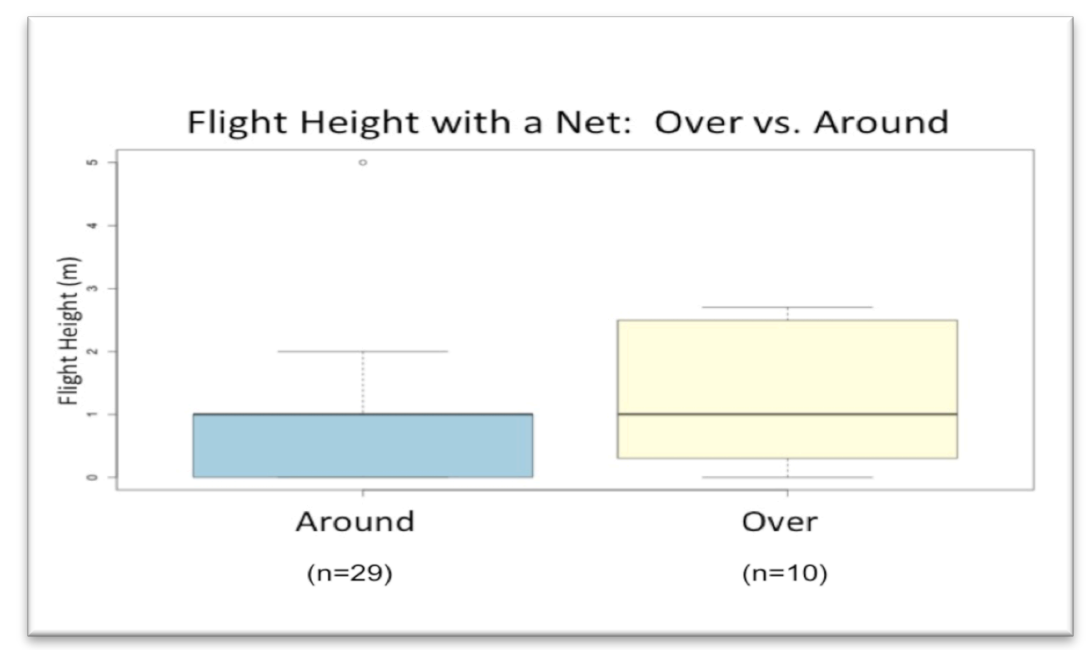

Figure 14: Range of flight height (in meters) of individuals that flew "around" vs. "over"

by Rebecca Jalene Littlejohn

Connecting habitat across roads 


\section{Results from pilot test: Attractants}

Pilot tests were conducted to see if butterflies could be attracted to a specific location. If so, butterflies could be encouraged to fly across a "virtual bridge" at a higher flight height than normal and over a road by attracting individuals to a higher flight height on either side of the road. Initial tests were conducted using treatments of color and flowers. Methods included setting out standing 1-meter poles made of PVC pipe in a meadow where Oregon silverspot butterflies were observed. Pilot treatments using colors and flowers were conducted by placing a different treatment on one of six poles in a meadow and observing the number of butterflies in the area vs. the number of butterflies that flew through or landed within one meter of the observed pole within a 10-minute observation period. Color treatments included red, yellow, and no color. Flower treatments included a variety of native flowering plants on the pole. None of the pilot tests provided useful results, so tests were suspended due to lack of resources to improve the quality of attractants and the short data collection time during flight season. It is not known whether the poles or attractants were influencing flight behavior or height. While these pilot tests did not provide useful results, attractants warrant additional study as a possible management strategy in addition to guiding barriers.

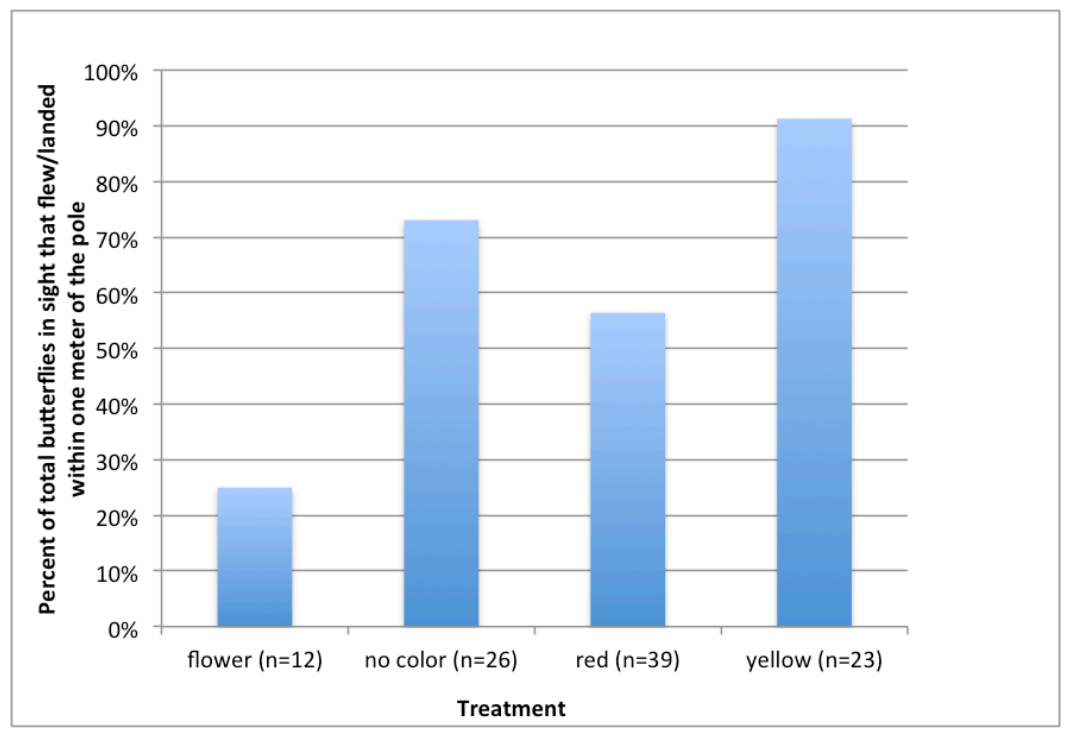

Figure 15: Figure shows the ratio of butterflies that landed or flew within one meter of the treatment pole to the total number of butterflies observed in the area prior to the observation period. No butterflies landed on any of the treatment poles during pilot tests.

by Rebecca Jalene Littlejohn

Connecting habitat across roads 